Research Paper

\title{
The Fanconi anemia pathway controls oncogenic response in hematopoietic stem and progenitor cells by regulating PRMT5- mediated p53 arginine methylation
}

\author{
Wei Du ${ }^{1,2}$, Surya Amarachintha ${ }^{1}$, Ozlem Erden ${ }^{1}$, Andrew Wilson ${ }^{1}$, Qishen Pang ${ }^{1,3}$ \\ ${ }^{1}$ Division of Experimental Hematology and Cancer Biology, Cincinnati, 45229 Ohio, USA \\ ${ }^{2}$ Divisions of Radiation Health,College of Pharmacy, UAMS, Little Rock, 72205 Arkansas, USA \\ ${ }^{3}$ Department of Pediatrics, University of Cincinnati College of Medicine, Cincinnati, 45229 Ohio, USA
}

Correspondence to: Qishen Pang, email: Qishen.pang@cchmc.org

Wei Du, email: wdu@uams.edu

Keywords: fanconi anemia, hematopoietic stem and progenitor cells, oncogenic stress, protein arginine methyltransferase 5 (PRMT5)

Received: October 13, 2015

Accepted: July 26, 2016

Published: August 05, 2016

\section{ABSTRACT}

The Fanconi anemia (FA) pathway is involved in DNA damage and other cellular stress responses. We have investigated the role of the FA pathway in oncogenic stress response by employing an in vivo stress-response model expressing the Gadd45 $\beta$-luciferase transgene. Using two inducible models of oncogenic activation (LSL-K-ras ${ }^{G 12 D}$ and $M_{y c}{ }^{E R}$ ), we show that hematopoietic stem and progenitor cells (HSPCs) from mice deficient for the FA core complex components Fanca or Fancc exhibit aberrant short-lived response to oncogenic insults. Mechanistic studies reveal that FA deficiency in HSPCs impairs oncogenic stress-induced $\mathbf{G}_{1}$ cell-cycle checkpoint, resulting from a compromised $\mathrm{K}$-ras ${ }^{\mathrm{G12D}}$-induced arginine methylation of p53 mediated by the protein arginine methyltransferase 5 (PRMT5). Furthermore, forced expression of PRMT5 in HSPCs from LSL-K-ras ${ }^{\mathrm{G12D}} / \mathrm{CreER}$-Fanca-/- mice prolongs oncogenic response and delays leukemia development in recipient mice. Our study defines an arginine methylation-dependent FA-p53 interplay that controls oncogenic stress response.

\section{INTRODUCTION}

Fanconi anemia (FA) is a rare inherited disease with at least 19 complementation groups identified thus far [1-7]. Mutations in any of the nineteen FA genes (FANCA-T) leads to clinical manifestations characterized by developmental abnormalities, progressive bone marrow failure and a high risk of developing cancer [1-3, 8]. The prominent role of the FA protein family has been implicated in the network of DNA damage response (DDR), which includes DNA repair pathways such as homologous recombination (HR) and non-homologous end-joining (NHEJ) [5, 9-12]. It is established that eight of FA proteins form a FA "core complex" (FANCA-C, E-G, L, and M), which catalyzes the monoubiquitylation of the FANCD2 and FANCI proteins, and activation of downstream DNA repair processes [1-3].

In response to oncogenic activation, normal cells induce genetically encoded programs, mainly growth arrest, apoptosis and senescence, which prevent deregulated proliferation and thus protect multicellular organisms from cancer progression [13-15]. It is known that oncogene-driven proliferation must be associated with inhibition of apoptosis and senescence to allow malignant outgrowth [16-18]. It has been postulated that functional loss of FA proteins renders cells a high predisposition to cancer transformation [1-3, 8, 19, 20]. However, how cells deficient in the FA pathway respond to oncogenic stress remains largely unknown.

The tumor suppressor p53 is a key component of the DNA damage response (DDR) network that activates vital damage containment procedures to restrict aberrant cell growth in response to DNA damage, oncogene activation, and loss of normal cell contacts by maintaining the balance between cell survival and apoptosis [21-24]. It is known that oncogene insults activate p53 [24, 25]. Highly regenerative tissues, such as blood, possess effective DNA damage responses (DDR) that balance long-term 
regeneration with protection from leukemogenesis [26]. Several recent studies using mouse models suggest a critical role for the p53 pathway in hematopoietic stem cell (HSC) self-renewal and quiescence [27-31] and precise regulation of p53 activity is likely to be important in determining the response of HSCs to DNA damage and oncogenic activation. Insufficient p53 activation would favor cell survival, but put cells at risk for loss of genomic integrity. In contrast, excessive p53 activation could compromise steady-state hematopoiesis and its recovery following exogenous marrow insult by causing too many cells to be eliminated [32]. In the context of FA, emerging evidence suggests that p53 deficiency may increase cancer development in patients with FA and FA mice [33-36]. Conversely, recent studies show that overactive p53 could cause hematopoietic stem and progenitor cell (HSPC) depletion in the BM of FA patients [37]. These studies corroborate a critical role of the FA proteins in cooperating with p53 in apoptosis and cell cycle checkpoint control after DNA damage induced by an exaggerated physiologic stress response.

In the present study, we employed an in vivo stressresponse model expressing the luciferase transgene under the control of the promoter of the stress-responsive gene Gadd $45 \beta$ and showed that HSPCs from mice deficient for the core complex components of the FA pathway, Fanca or Fancc, exhibited aberrant response to oncogenic stress. In a sharp contrast to wild-type controls, $\mathrm{Fanca}^{-/}$ or $\mathrm{Fancc}^{-/}$HSPCs showed a short-lived response to oncogenic activation. Significantly, we demonstrated that disruption of the FA pathway compromised the oncogene K-ras ${ }^{\mathrm{G} 12 \mathrm{D}}$-induced arginine methylation of $\mathrm{p} 53$ mediated by the protein arginine methyltransferase 5 (PRMT5). Therefore, our study demonstrates for the first time that oncogenic stress orchestrates a p53-dependent response that is controlled by PRMT5-mediated arginine methylation and identifies the FA pathway as an integral part of this versatile cellular mechanism.

\section{RESULTS}

\section{Disruption of the FA pathway induces a short-lived response to oncogenic stress in vitro}

To investigate how cells with a defective FA pathway respond to oncogenic stress, we employed two inducible models of oncogenic activation: 1) the LSL-K-ras ${ }^{\mathrm{G} 12 \mathrm{D}} / \mathrm{CreER}$ mouse model [38], in which Cremediated recombination leads to deletion of a translational termination sequence (Lox-Stop-Lox) and expression of the oncogenic Kras ${ }^{\mathrm{G} 12 \mathrm{D}}$ protein; 2) A retroviral vector delivered proto-oncogene $\mathrm{Myc}^{\mathrm{ER}}$ system [39], in which oncogene activation is induced and controlled by 4-OHT or tamoxifen exposure. The reason that we chose the K-ras ${ }^{\mathrm{G} 12 \mathrm{D}}$ model for these detailed studies was two-fold: 1) it is an authentic in-vivo knock-in model, which enabled us to analyze oncogenic response under near physiological conditions; and 2) it is an established myeloid leukemia model, which has relevance to FA disease progression. We first examined the sensitivity of hematopoietic stem and progenitor (HSPC; LSK) cells (Figure S1A), isolated from LSL-K-ras ${ }^{\mathrm{G} 12 \mathrm{D}} / \mathrm{CreER}$ mice or infected with the Myc ${ }^{\mathrm{ER}}$ retrovirus, to oncogene activation by in vitro culturing the cells in the presence of 4-Hydroxytamoxifen (4-OHT) for 48 hours $[40,41]$ followed by plating in cytokinesupplemented methycellulose medium. We found that K-ras or Myc activation reduced colony formation in both WT and $\mathrm{FanCa}^{-/}$or $\mathrm{Fancc}^{-/}$progenitors (Figures 1A, $\mathrm{S} 1 \mathrm{~B})$, which accompanied by increased apoptosis 24-96 $\mathrm{h}$ after 4-OHT induction (Figures 1B, 1C, S1C, S1D).

To determine the kinetics of oncogenic response, we assessed $\mathrm{G}_{1}$ cell cycle arrest induced by K-ras or Myc activation [42, 43]. Hochest 33342/Ki67 staining showed significantly increased percentage of LSK cells arrested in $\mathrm{G}_{1}$ phase in both WT and $\mathrm{FanCa}^{-/-}$or $\mathrm{FanCc}^{-/}$after 4-OHT treatment (Figures 1D, 1E, S1E, S1F). However, oncogenic activation of K-ras or Myc induced prolonged $\mathrm{G}_{1}$ arrest in WT LSK cells (Figures 1D, 1E, S1E, S1F). In contrast, $\mathrm{Fanca}^{-/-}$or $\mathrm{Fancc}^{-/-}$LSK cells showed a shortlived $\mathrm{G}_{1}$ arrest with a peak at 48 hours and returned to cycle at 72 hours after 4-OHT induction (Figures 1D, 1E, $\mathrm{S} 1 \mathrm{E}, \mathrm{S} 1 \mathrm{~F})$. These in vitro results demonstrate an aberrant short-lived oncogenic stress response in FA HSPCs.

\section{Disruption of the FA pathway induces a short-lived response to oncogenic stress in vivo}

We next examined oncogenic response in vivo by crossing the FA mice to the Luc-Gadd $45 \beta$ mice, which express the luciferase transgene under the control of the promoter of the stress-responsive gene Gadd45 $\beta$ [44] and allow for non-invasive in vivo imaging stressinduced expression of the luciferase marker. Gadd $45 \beta$ is well established for its diverse roles in cell cycle control, cell survival, apoptosis, DNA damage repair and the maintenance of genomic stability [45]. Gadd $45 \beta$ can also act as a stress sensor in the development of hematopoietic malignancies like leukemia [46]. We assessed oncogenic response in the recipients with similar donor chimerism (Figure S2), transplanted with BM LSK cells expressing Luc-Gadd $45 \beta$ and LSL-K-ras ${ }^{\mathrm{G} 12 \mathrm{D}} / \mathrm{CreER}$ or $\mathrm{Myc}^{\mathrm{ER}}$, by monitoring the kinetics of luciferase expression at different time points after tamoxifen injection. Consistent with the in vitro observations described above, the recipients transplanted with WT $\left(\mathrm{FanCa}^{+/+}\right.$or $\mathrm{FancC}^{+/+}$) LSK cells expressing LSL-K-ras ${ }^{\mathrm{G} 12 \mathrm{D}} / \mathrm{CreER}$ (Figure 2A, 2B, 2E) or $\mathrm{Myc}^{\mathrm{ER}}$ (Figure 2C, 2D, 2F) exhibited a persistent induction of luciferase expression even 48 hours after tamoxifen injection. In contrast, the recipients transplanted with FA-deficient $\left(\mathrm{FanCa}^{-/-}\right.$or $\mathrm{FanCC}^{-/-}$) LSK cells expressing LSL-K-ras ${ }^{\mathrm{G} 12 \mathrm{D}} / \mathrm{CreER}$ (Figure 2A, 2B, 2E) or $\mathrm{Myc}^{\mathrm{ER}}$ (Figure 2C, 2D, 2F) showed a typical short-lived response 
with a peak at 4 hours and declined from 6-24 hours after induction. Taken together, HSPCs deficient for the Fanca or Fancc gene displayed abnormal short-lived response to oncogenic stress. In addition, we observed a similar pattern of less long-lived oncogenic response in primary mouse embryonic fibroblasts (MEFs) isolated from Luc-LSL-K-ras/CreER-Fanca ${ }^{-/-}$mice (Figure S3), suggesting that this abnormal oncogenic response is not restricted to HSPCs.

\section{Deregulated $G_{1}$ checkpoint regulators correlated with short-lived oncogenic response}

The observation that $\mathrm{FanCa}^{-/-}$and $\mathrm{Fancc}^{-/}$HSPCs exhibited an abnormal short-lived response to K-ras and c-Myc activation prompted us to investigate the underlying molecular mechanism. Since activation of oncogenes including K-ras and c-Myc induces senescencelike cell growth arrest in a variety of cell types $[47,48]$ and since we observed a short-lived $\mathrm{G}_{1}$ arrest induced by K-ras or c-Myc activation in $\mathrm{FanCa}^{-/-}$and $\mathrm{Fancc}^{-/-}$LSK cells (Figures 1D, 1E, S1E, S1F), we analyzed oncogeneinduced expression of $\mathrm{G}_{1}$ arrest-associated cell-cycle regulators in $\mathrm{K}-\mathrm{Ras}^{\mathrm{G} 12 \mathrm{D}}$-expressing HSPCs with a focus on p1 $15^{I N K b}, p 16^{I N K 4 a}, A R F$ and $p 21^{\text {Cip } 1 / W A F 1}[49,50]$. Indeed, it is known that the K-ras ${ }^{\mathrm{G} 12 \mathrm{D}}$ mutation is frequently associated with juvenile myelomonocytic leukemia (JMML) and acute myeloid leukemia (AML) [51]. LSK cells freshly isolated from WT and $\mathrm{FanCa}^{-/-}$littermates expressing the LSL-K-ras ${ }^{\mathrm{G} 12 \mathrm{D}} / \mathrm{CreER}$ transgenes were treated with 4-OHT at different time points to determine the kinetics of oncogenic induction of the $\mathrm{G}_{1}$ arrest-associated cellcycle regulators. Interestingly, three of the four $\mathrm{G}_{1}$ arrest-associated cell-cycle regulators, namely $p 16^{I N K 4 a}$,

A

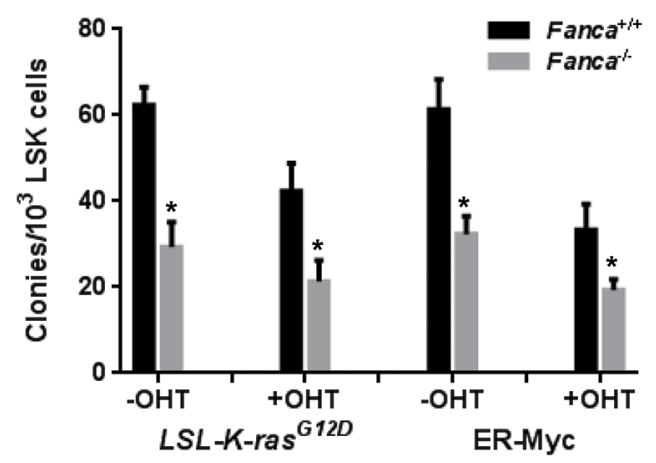

B
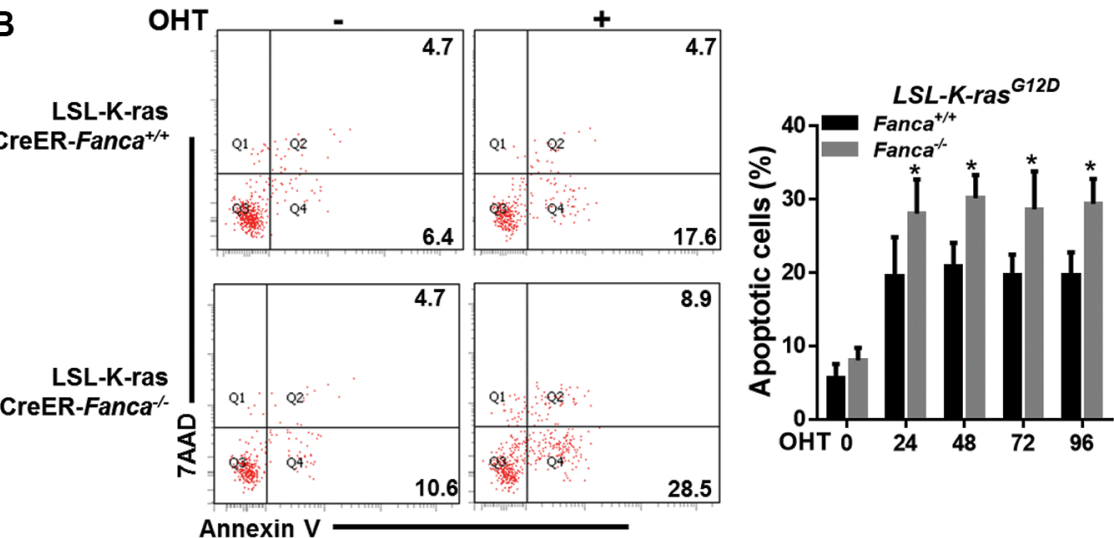

C
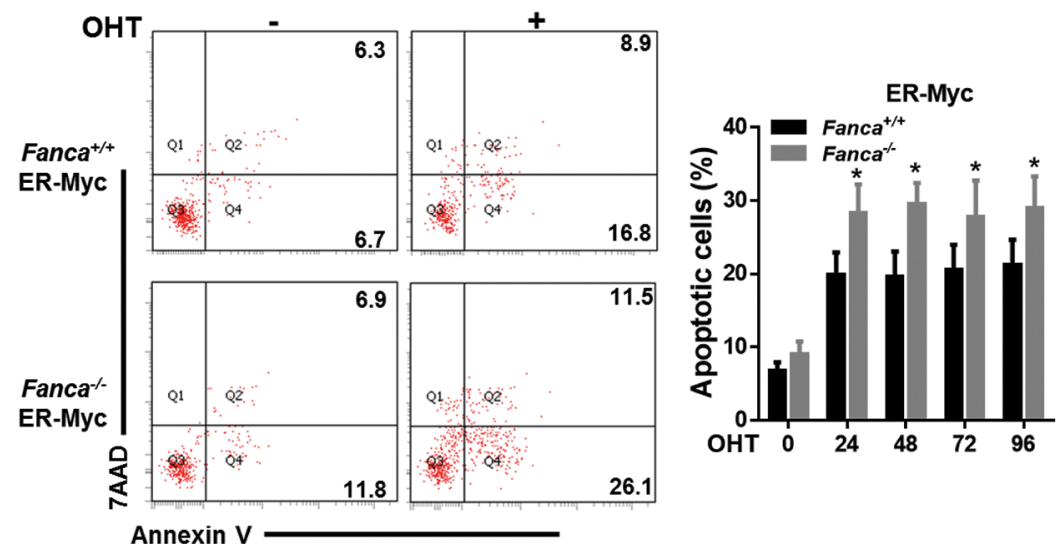
D
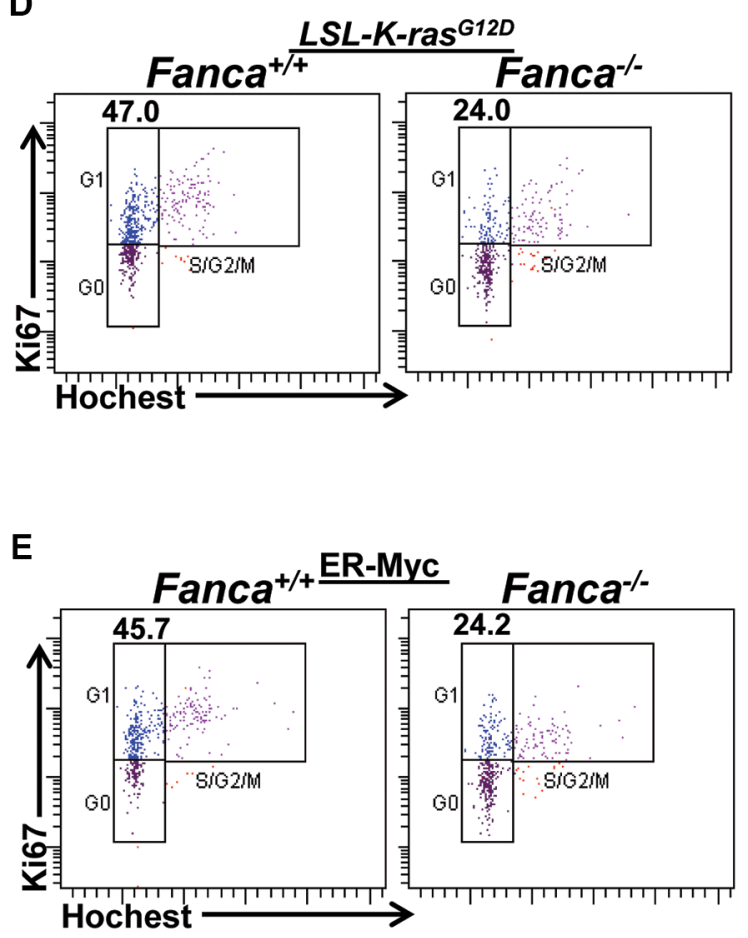

E
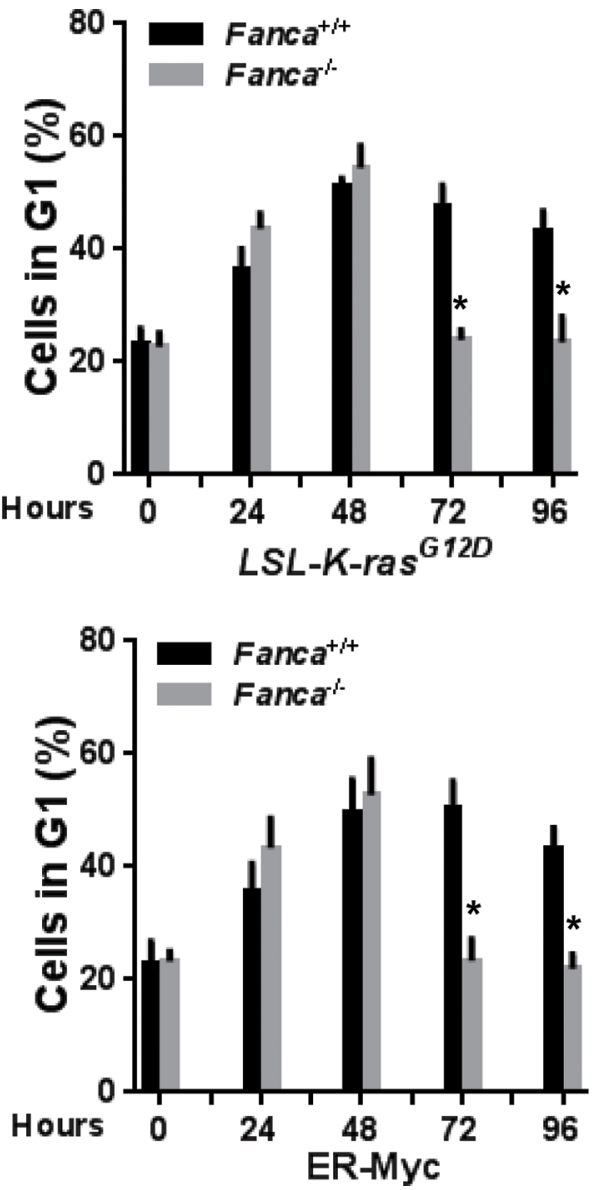

Figure 1: Disruption of the FA pathway induces a short-lived response to oncogenic stress in vitro. (A) Oncogenic stress compromises colony formation capacity of FA HSPCs. LSK cells (Lin-Sca1 ${ }^{+} \mathrm{c}-\mathrm{kit}^{+}$cells) isolated from LSL-Fanca ${ }^{++/} / \mathrm{K}-\mathrm{ras} / \mathrm{CreER}$ and

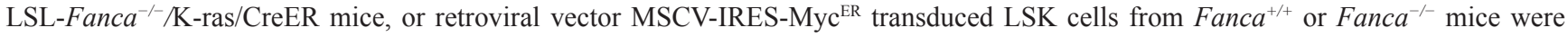
in vitro culture in the presence of 4-OHT for 48 hours followed by plating in cytokine-supplemented methycellulose medium. Colonies were enumerated on day 7 after plating. Results are means \pm standard deviation (SD) of 3 independent experiments ( $n=9$ per group). (B) K-ras activation induces apoptosis in FA HSCs. LSK cells (Lin-Sca ${ }^{+}$c-kit ${ }^{+}$cells) isolated from LSL-Fanca ${ }^{+/+} / \mathrm{K}-\mathrm{ras} / \mathrm{CreER}$ and LSL$\mathrm{Fanca}^{-/} / \mathrm{K}$-ras/CreER mice were subjected to Flow cytometric analysis for apoptosis by Annexin V/7AAD staining at different time points. Representative images at time 0 and $24 \mathrm{~h}$ after 4-OHT induction (left) and quantification (right) were shown. Results are means \pm standard deviation (SD) of 3 independent experiments ( $n=6$ per group). (C) Myc activation induces apoptosis in FA HSCs. Retroviral vector MSCVIRES-Myc ${ }^{\mathrm{ER}}$ transduced LSK cells from $\mathrm{Fanca}^{+/+}$or $\mathrm{Fanca}^{-/-}$mice were subjected to Flow cytometric analysis for apoptosis by Annexin V/7AAD staining at different time points. Representative images at time 0 and $24 \mathrm{~h}$ after $4-O H T$ induction (left) and quantification (right) were shown. Results are means \pm standard deviation (SD) of 3 independent experiments ( $n=9$ per group). (D) Activation of K-ras leads to short-lived $\mathrm{G}_{1}$ arrest in FA cells. Cells described in (B) were cultured in the presence of 4-OHT for 2 hours then released in fresh medium for the indicated time intervals, followed by cell cycle profiling by Hochest33324/Ki67 staining. Representative images (left) and quantification (right) were shown. Results are means \pm standard deviation (SD) of 3 independent experiments ( $n=6$ per group). (E) Activation of Myc leads to short-lived $\mathrm{G}_{1}$ arrest in FA cells. Cells described in (C) were cultured in the presence of 4-OHT for 2 hours then released in fresh medium for the indicated time intervals, followed by cell cycle profiling by Hochest33324/Ki67 staining. Representative images (left) and quantification (right) were shown. Results are means \pm standard deviation (SD) of 3 independent experiments ( $n=9$ per group).

$p 19^{A r f}$ and $p 21^{\text {Cipl/WAF1 }}$, exhibited the pattern of short-lived response to K-ras activation in $\mathrm{Fanca}^{-/-} \mathrm{HSPCs}$. That is, K-ras activation orchestrated the expression of these cell-cycle regulators that burst at 4 hours then receded to the basal level at 24 hours (Figure 3A). In contrast, the WT LSK cells displayed a persistent response during the 4-24 hours period (Figure 3A). These results suggest that a pathway regulating the expression of $p 16^{I N K 4 a}, p 19^{A r f}$ and $p 21^{\text {Cipl/WAF1 }}$ may be responsible for the short-lived oncogenic stress response in $\mathrm{Fanca}^{-/-}$HSPCs.

\section{Short-lived oncogenic response involves p53 signaling}

Since $p 21^{\text {Cipl/WAFl }}$ is a p53 target and $p 19^{A r f}$ induction by K-ras requires p53 [49, 50, 52], we determined if p53 was essential for the prolonged oncogenic response in HSPCs. We deleted the Trp53 gene in our $\mathrm{FanCa}^{-/-}$LSLK-ras ${ }^{\mathrm{G} 12 \mathrm{D}} / \mathrm{CreER}$ mice, and evaluated the requirement of p53 for K-ras-induced OIS (oncogene-induced senescence) [53] using $p 16^{I N K 4 a}$ expression as a surrogate. 
A

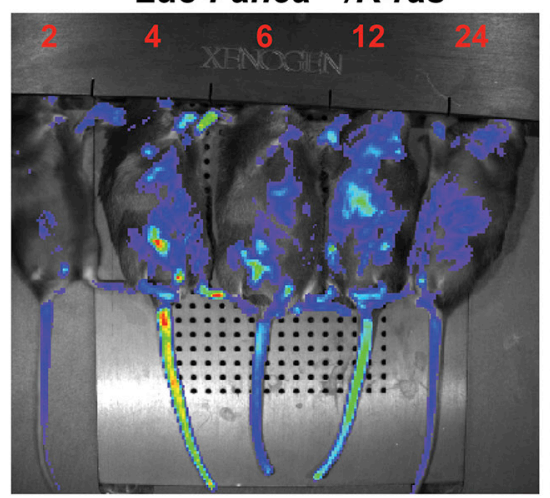

B $\quad$ Luc-Fancc $^{+/+} /$K-ras

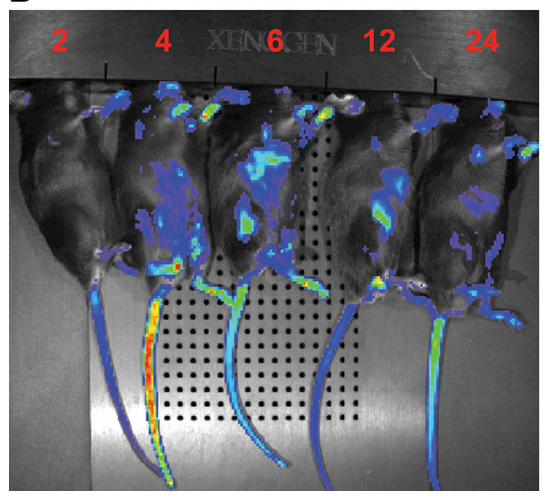

C

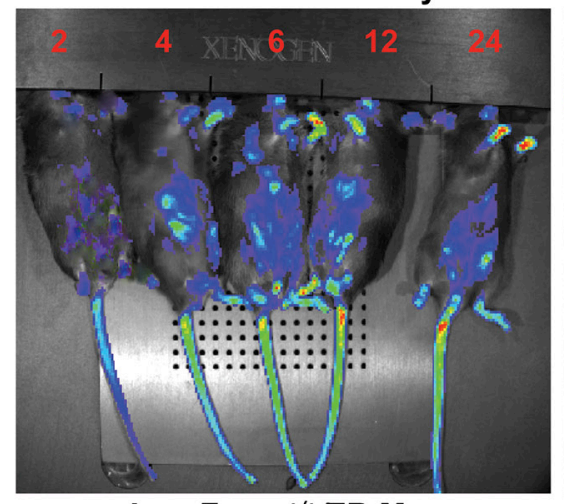

D

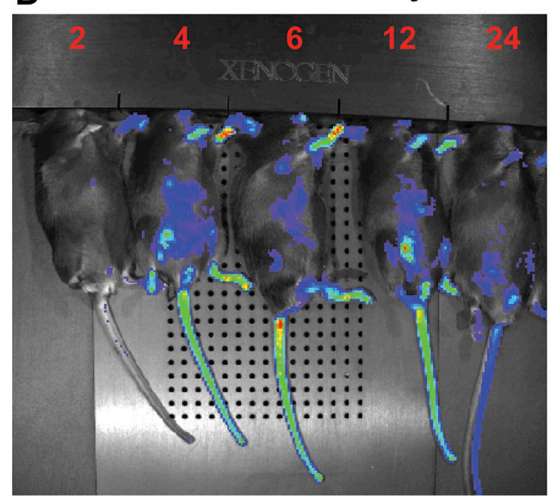

Luc-Fanca-//K-ras

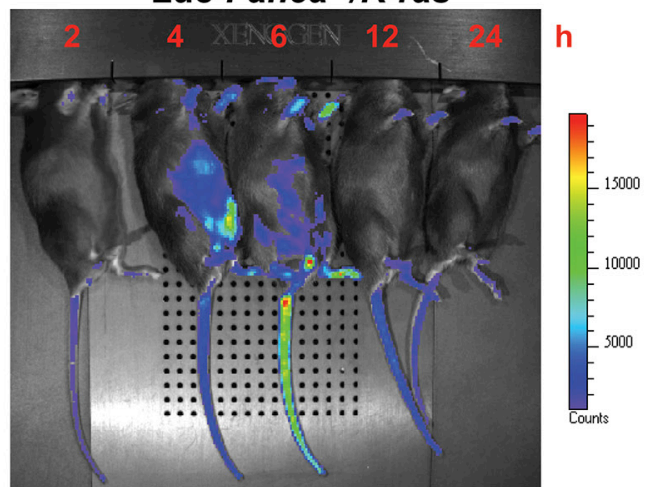

\section{Luc-Fancc-//K-ras}
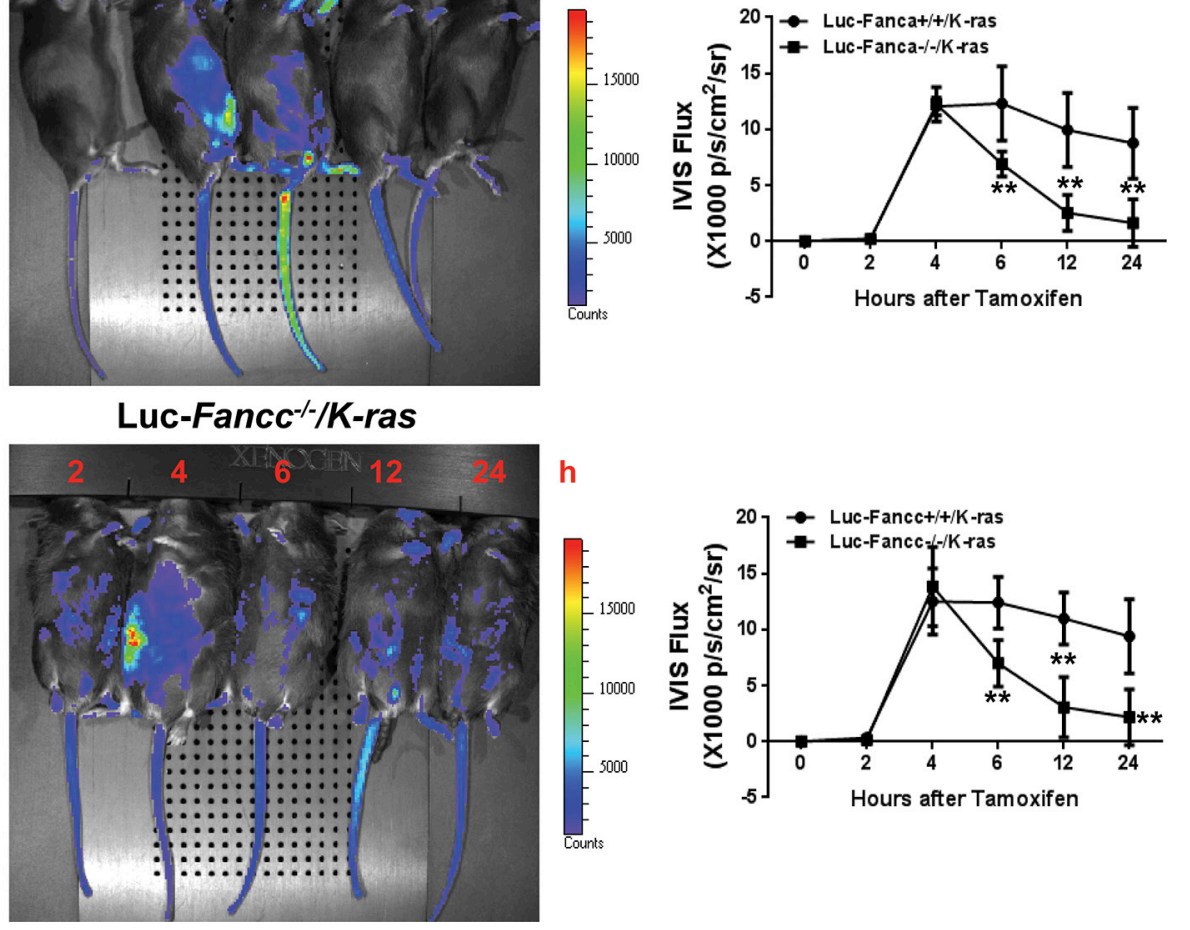

$$
\text { (n) }
$$
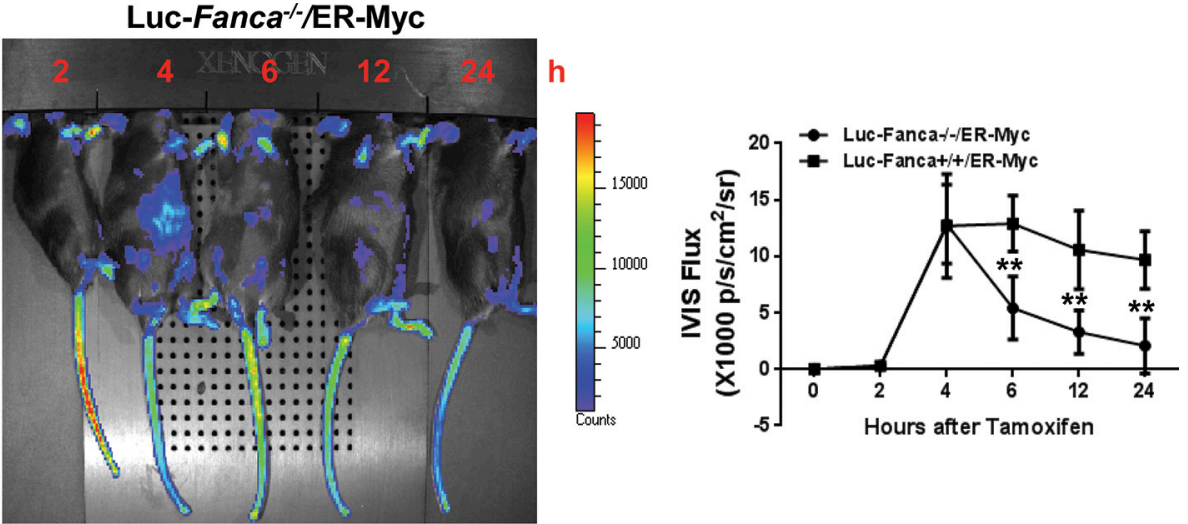

\section{Luc-Fancc-/ER-Myc}
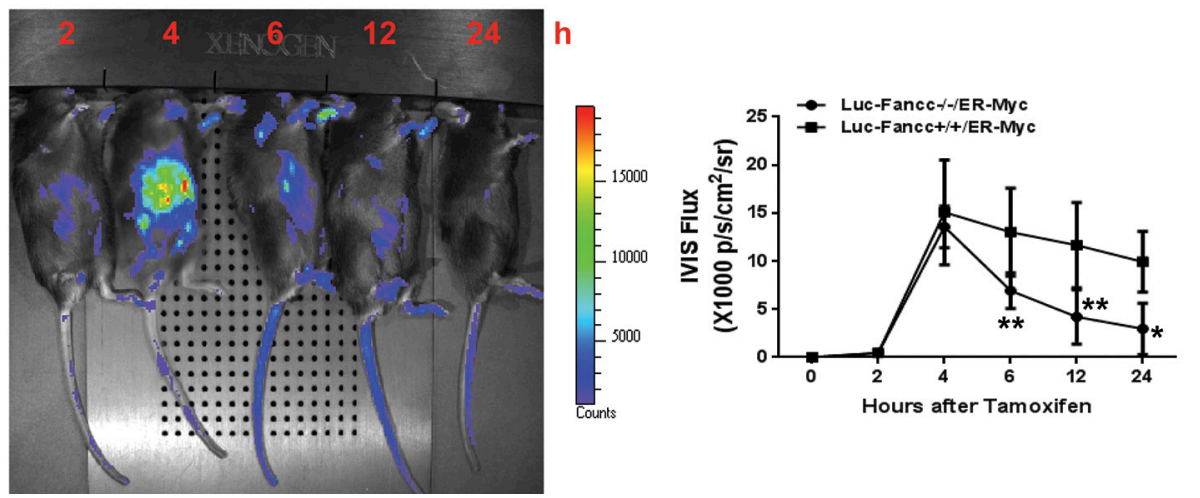
E

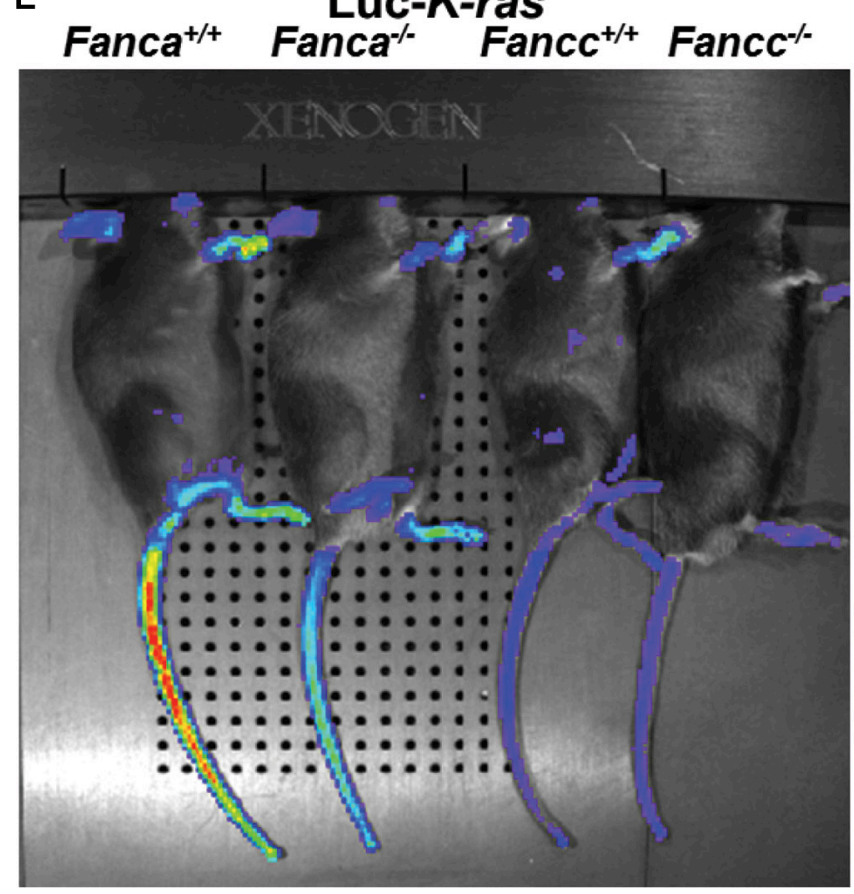

F

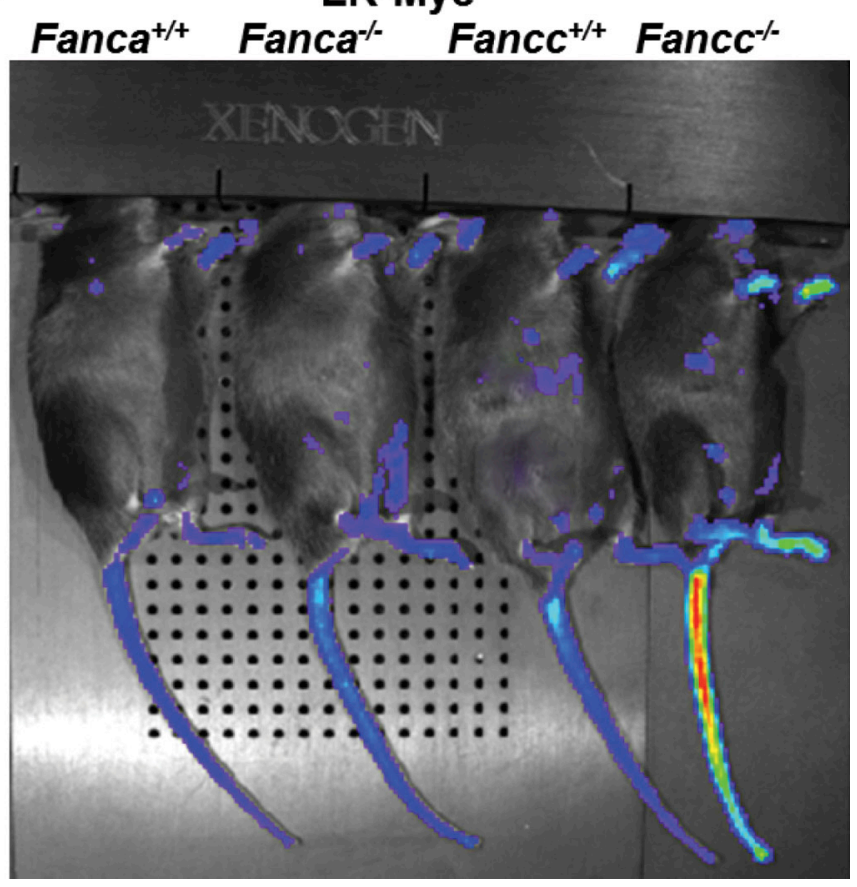

Figure 2: Disruption of the FA pathway induces a short-lived response to oncogenic stress in vivo. (A, B) FA mice exhibit short-lived response to K-ras activation. 1,000 LSK cells from Luc-LSL-K-ras/CreER-Fanca ${ }^{+/+}$or 2,000 LSK cell from Luc-LSL-Kras/CreER-Fanca ${ }^{-/}$mice (A) along with $3 \times 10^{5}$ BM cells from congenic BoyJ mice were transplanted into lethally irradiated BoyJ recipients. 4-month post BMT, the recipients were i.p injected with single dose of Tamoxifen followed by IVIS imaging at the indicated time points. Luminescence scale is in $\mathrm{p} / \mathrm{s} / \mathrm{cm} 2 / \mathrm{sr}$. Similar experiments were conducted on $\mathrm{Fancc}^{-/}$mice (B). (C, D) FA mice exhibit short-lived response to Myc ${ }^{\mathrm{ER}}$ activation. 1,500 retroviral vector MSCV-IRES-Myc ${ }^{\mathrm{ER}}$ transduced Luc-Fanca ${ }^{+/+}$cells or 3,000 transduced Luc-Fanca ${ }^{--}$cells (C) along with $3 \times 10^{5} \mathrm{BM}$ cells from congenic BoyJ mice from recipient mice were transplanted into lethally irradiated BoyJ recipients. 4-month post BMT, the recipients were i.p injected with single dose of Tamoxifen followed by IVIS imaging at the indicated time points. Luminescence scale is in $\mathrm{p} / \mathrm{s} / \mathrm{cm} 2 / \mathrm{sr}_{\text {r Similar experiments were conducted on Fancc }}^{-/}$mice (D). The bioluminescent image signals were quantified using LiveImage Pro. 2.0 software. Results are means \pm standard deviation (SD) of 3 independent experiments ( $n=6$ per group). (E, F) Minimum bioluminescence of Luc mice without tamoxifen injection (the "0" time-point controls). Luminescence scale is in $\mathrm{p} / \mathrm{s} / \mathrm{cm} 2 / \mathrm{sr}$.

As illustrated in Figure 3B, loss of p53 not only abrogated the long-lasting (4-24 hours) K-ras-induced $p 16^{I N K 4 a}$ expression in WT LSL-K-ras ${ }^{\mathrm{G} 12 \mathrm{D}} / \mathrm{CreER}$ LSK cells but also abolished the short-lived (4 hours) response to K-ras activation in $\mathrm{Fanca}^{-/-}$LSL-K-ras ${ }^{\mathrm{G} 12 \mathrm{D} / \mathrm{CreER} \text { LSK }}$ cells (Figure 3B, Upper). Consistently, p53 inactivation completely abated $p 21^{\text {Cipl/WAFI }}$ expression in response to K-ras activation in both WT and $\mathrm{Fanca}^{-/-}$LSL-K-ras ${ }^{\mathrm{G} 12 \mathrm{D} /}$ CreER LSK cells (Figure 3B, Lower). Thus, an alteration in p53 protein level or activity during the 4-24 hours period may account for the short-lived oncogenic response in $\mathrm{Fanca}^{-/-}$LSL-K-ras ${ }^{\mathrm{G} 12 \mathrm{D}} / \mathrm{CreER}$ LSK cells.

\section{Aberrant oncogene-induced arginine methylation of $p 53$ contributes to short-lived oncogenic response}

We next examined the status of p53 in WT and

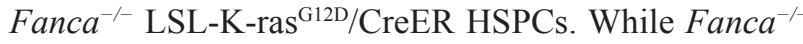
BM lineage-negative (Lin') cells (enriched for HSPCs) showed higher levels of p53 protein than WT cells, we did not observe significant difference in the kinetics of p53 induction between WT and $\mathrm{Fanca}^{-/}$cells during the 2-24 hours period of K-ras activation (Figure 3C). This suggests the aberrant oncogenic response observed in $\mathrm{Fanca}^{-/-}$HSPCs was most likely resulted from an altered p53 activity. Since most if not all of the p53 activities are controlled by post-translational modifications [54], we determined phosphorylation, acetylation and methylation of p53 in WT and $\mathrm{Fanca}^{-/}$LSL-K-ras ${ }^{\mathrm{G} 12 \mathrm{D}} / \mathrm{CreER}$ HSPCs. The $\mathrm{p} 53$ protein was enriched by immunoprecipitation using lysates of BM Lin cells treated with 4-OHT for different time intervals, and probed for forms of p53 modified by phosphorylation, acetylation or methylation under oncogenic stress. We found similar levels of phosphorylation, acetylation, or lysine methylation of p53 between WT and $\mathrm{FanCa}^{-/-}$cells at different time points after oncogene induction (Figure 3D). However, K-rasinduced arginine methylation of $\mathrm{p} 53$ was peaked at 2 hours and almost completely abated after 8-hour induction with 4-OHT in $\mathrm{Fanca}^{-/-}$Lin- cells (Figure 3D), reminiscent of the short-lived oncogenic response described above. Thus, 
these results identified an aberrant oncogene-induced arginine methylation of $\mathrm{p} 53$ as a potential mechanism for the short-lived oncogenic stress response in FA HSPCs.

\section{Ectopic expression of PRMT5 prevents short-lived oncogenic response}

Protein arginine methylation is mediated by a group of protein arginine methyltransferases (PRMTs)
[55]. Three of the PRMTs (PRMT1, 4 and 5) have been implicated in regulating p53-mediated transcription [50-52]. We thus examined the levels of these PRMTs

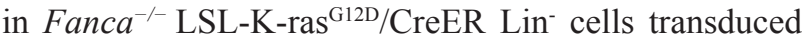
with Venus or Venus-FANCA lentivirus and then subjected to oncogenic stress. We found that the level of PRMT5 underwent progressive decline after 4 hours of 4-OHT

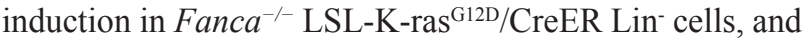
re-expression of the FANCA gene in these cells stabilized
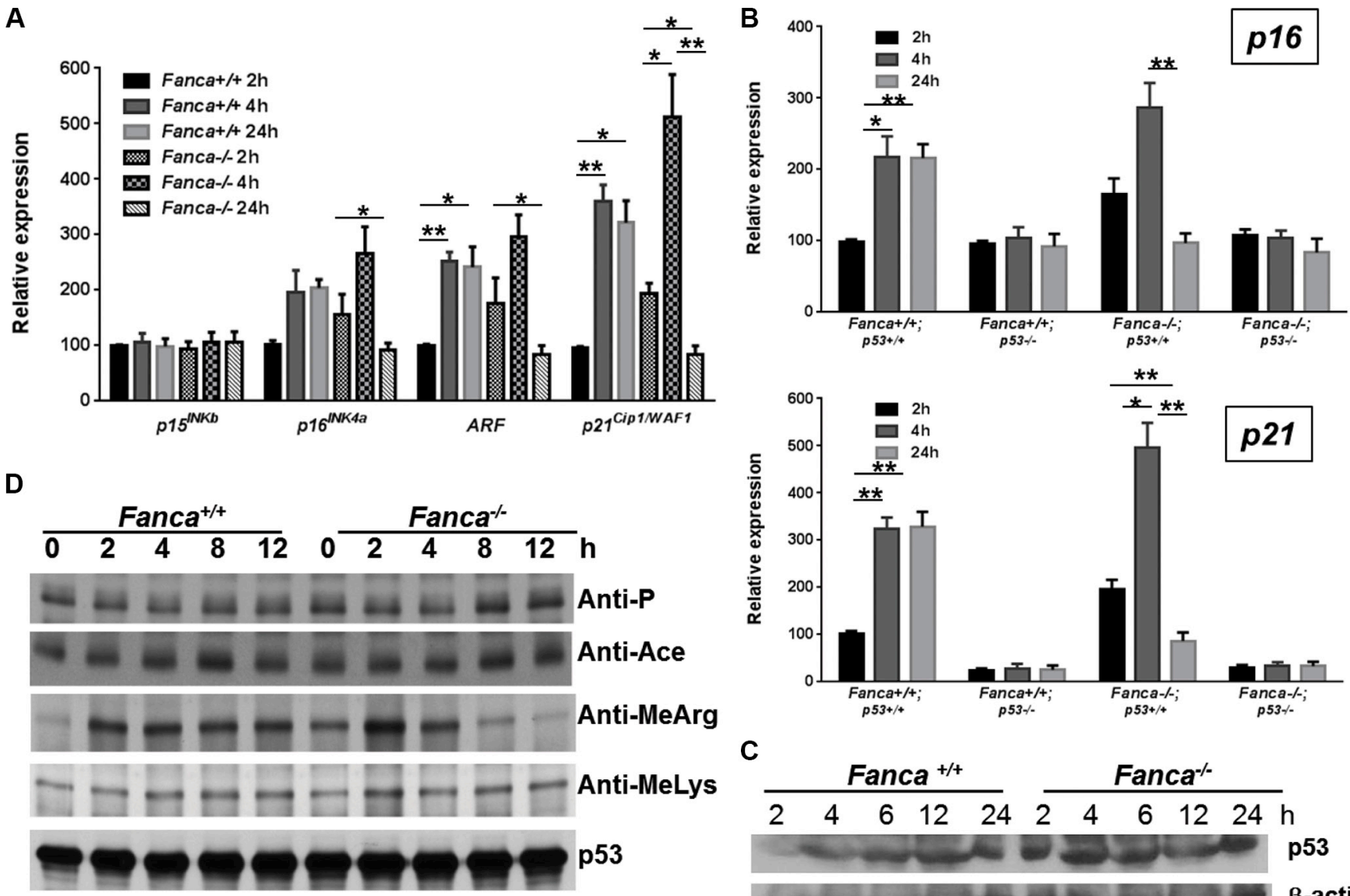

C

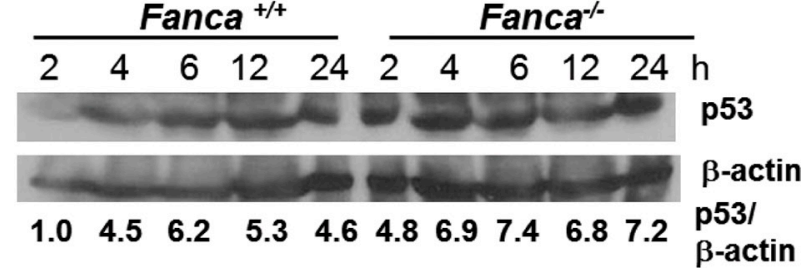

Figure 3: Aberrant oncogene-induced arginine methylation of p53 contributes to short-lived oncogenic response. (A) Short-lived response of $\mathrm{G}_{1}$-arrest-associated cell-cycle regulators in response to oncogenic stress in FA HSPCs. LSK cells isolated from Luc-LSL-Fanca ${ }^{+/+} / \mathrm{K}$-ras/CreER or Luc-LSL-Fanca ${ }^{-/} / \mathrm{K}$-ras/CreER mice were cultured in the presence of 4-OHT for 2 hours then released in fresh medium for the indicated time intervals. RNA was extracted at different time points for qPCR analysis using primers listed in Table S1. Levels of the expression in each sample were normalized to the level of GAPDH mRNA, and the expression levels of the $\mathrm{Fanca}^{+/+}$samples at $2 \mathrm{~h}$ were normalized as 100. (B) p53 is essential for the prolonged oncogenic response in HSPCs. LSK cells isolated

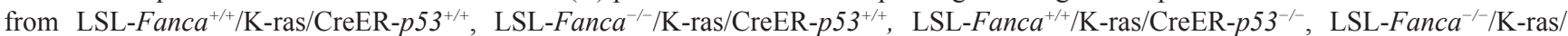
CreER- $p 53^{--1}$ mice were cultured in the presence of 4-OHT for 2 hours then released in fresh medium for the indicated time intervals. RNA was extracted at different time points for qPCR analysis using primers for $p 16$ (Upper) and p21 (Lower) Samples were normalized to the level of GAPDH mRNA. (C) K-ras activation does not alter p53 level. BM Lin cells from Luc-LSL-Fanca ${ }^{+/+} / \mathrm{K}-\mathrm{ras} / \mathrm{CreER}$ or LucLSL-Fanca $\mathrm{F}^{-/} / \mathrm{K}$-ras/CreER mice were cultured in the presence of 4-OHT for 2 hours then released in fresh medium for the indicated time intervals. Whole cell lysates were prepared then subjected to immunoblot using antibodies against p53 or $\beta$-actin. p53: $\beta$-actin ratio in each sample was calculated. The WT control sample at $0 \mathrm{~h}$ time point has been normalized as 1 . (D) FA deficiency leads to short-lived arginine methylation of $\mathrm{p} 53$ in response to oncogene activation. BM Lin ${ }^{-}$cells from Luc-LSL-Fanca/+/K-ras/CreER or Luc-LSL-Fanca ${ }^{-/-} / \mathrm{K}-\mathrm{ras} /$ CreER mice were cultured in the presence of 4-OHT for 2 hours then released in fresh medium for the indicated time intervals. Whole cell lysates were prepared, and subjected to immunoprecipitation using anti-p53 antibody followed by immunoblotting with antibodies against phosphor-serine, acetylated lysine, methylated lysine, mono-methyl arginine or p53, respectively. 
the PRMT5 protein during the 24-hour period of 4-OHT induction (Figure 4A).

The correlation between aberrant oncogene-induced arginine methylation of $\mathrm{p} 53$ accompanied by a progressive decline in PRMT5 and the short-lived oncogenic stress response in FA HSPCs prompted us to determine whether restoring the level of PRMT5 could lengthen the oncogenic response in FA HSPCs. To this end, we ectopically expressed GFP or GFP-PRMT5 in WT and $\mathrm{Fanca}^{-/-} \mathrm{Lin}^{-}$ cells expressing the Luc-LSL-K-ras ${ }^{\mathrm{G} 12 \mathrm{D}} / \mathrm{CreER}$ cassette by lentiviral transduction (Figure S4A). The transduced $\left(\mathrm{GFP}^{+}\right)$cells were then sorted for LSK cells and used for analyzing oncogenic response in vitro and in vivo. First, we analyzed the sorted $\mathrm{GFP}^{+}$LSK cells for the kinetics of $p 16^{I N K 4 a}$ expression at different time-points of K-ras ${ }^{\mathrm{G} 12 \mathrm{D}}$ induction following 4-OHT treatment. We found that ectopic expression of PRMT5 completely abrogated the short-lived K-ras-induced $p 16^{I N K 4 a}$ expression in $\mathrm{Fanca}^{-1}$ LSK cells (Figure 4B). Lentiviral expression of PRMT5 did not have effect on K-ras-induced $p 16^{I N K 4 a}$ expression in WT LSK cells (Figure S4B).

To specifically demonstrate the effect of ectopic expression of PRMT5 on p53 response, we determined the kinetics of oncogene-induced expression of the p53 target $p 21^{\text {Cip } 1 / W A F 1}$ using vector- or PRMT5-transduced LSK

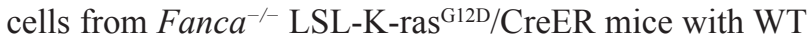
or p53-null background. As illustrated in Figure 4C, forced expression of PRMT5 showed a prolonged pattern, similar to that seen in WT LSK cells (Figure 3B), of $p 21^{\text {Cip } 1 / W A F I}$ expression in response to K-ras activation in p53-sufficient

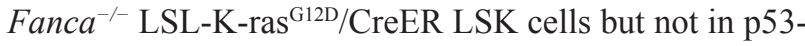
defficient $\mathrm{Fanca}^{-/}$LSL-K-ras ${ }^{\mathrm{G} 12 \mathrm{D}} / \mathrm{CreER}$ LSK cells (Figure 4C). This result suggests that p53 is at least one of the targets of ectopically expressed PRMT5 in response to K-ras ${ }^{\mathrm{G} 12 \mathrm{D}}$ in these LSK cells.

\section{Forced expression of PRMT5 delays leukemia}

To determine the effect of ectopic expression of PRMT5 on oncogenic response in vivo, we transplanted the transduced $\left(\mathrm{GFP}^{+}\right) \mathrm{WT}$ and $\mathrm{Fanca}^{-/-}$Luc-LSL-K-

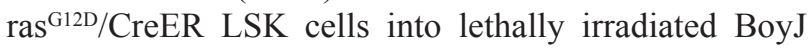
recipients. Four months later, the recipients were treated with tamoxifen and assessed oncogenic response by monitoring the kinetics of luciferase expression at different time points. It appeared that exogenous expression of PRMT5 not only lengthened but also enhanced the activated K-ras response in the progeny of donor $\mathrm{Fanca}^{-1}$ Luc-LSL-K-ras ${ }^{\mathrm{G} 12 \mathrm{D}} / \mathrm{CreER}$ HSPCs (Figures 4D, S4C). Lentiviral expression of PRMT5 also augmented K-rasinduced luciferase expression in WT donor-derived cells (Figure S4D). Furthermore, K-ras ${ }^{\mathrm{G} 12 \mathrm{D}}$-induced leukemia was significantly delayed in recipient mice transplanted with $\mathrm{Fanca}^{-/}$Luc-LSL-K-ras ${ }^{\mathrm{G} 12 \mathrm{D}} / \mathrm{CreER}$ LSK cells expressing PRMT5 compared with the recipient mice of donor $\mathrm{Fanca}^{-/-}$Luc-LSL-K-ras ${ }^{\mathrm{G} 12 \mathrm{D} / \mathrm{CreER} \text { LSK cells }}$ carrying the vector control virus (Figure 4E). Further characterization of the leukemic mice showed that the recipient mice transplanted with the $\mathrm{Fanca}^{-/-}$Luc-LSLK-ras ${ }^{\mathrm{G} 12 \mathrm{D}} / \mathrm{CreER}$ LSK cells developed myeloid leukemia, as characterized by increased white blood cells (WBCs) in the peripheral blood, anemia, and infiltration of myeloid blasts in the spleen and bone marrow (Figure 4F-4H). Collectively, these results link attenuated PRMT5 activity to the short-lived oncogenic stress response and leukemia development in FA HSPCs.

We further examined the molecular and cellular effects of forced expression of PRMT5 by analyzing the levels of p53 arginine methylation, the transcriptional activation of $\mathrm{p} 53$, the activity of DNA damage response kinases ATM and ATR, and cell cycle status in the leukemic cells. As expected, ectopic PRMT5 expression increased arginine methylation of p53 in K-ras ${ }^{\mathrm{G} 12 \mathrm{D}}$ expressing WT and $\mathrm{Fanca}^{-/}$leukemic cells (Figure 5A). In contrast to an increased expression of the p53 target gene in cell-cycle control, p21 Cipl/WAF1 (Figure 4C), forced expression of PRMT5 did not enhance expression of several major p53 apoptotic target genes like Bax, Puma, or Noxa in these leukemic cells (Figure 5B). PRMT5 expression did not increase the activity of the key DNA damage response kinases ATM and ATR, using phosphorylation of $\mathrm{CHK} 1$ and $\mathrm{CHK} 2$ as the respective surrogate (Figure 5C). However, forced expression of PRMT5 prolonged the short-lived $\mathrm{G}_{1}$ arrest induced by K-ras activation in $\mathrm{Fanca}^{-/-}$leukemic cells (Figure 5D). These results suggest that PRMT5 may exert its function via the $\mathrm{p} 53 / \mathrm{G}_{1}$ cell-cycle checkpoint rather than the ATM/ $\mathrm{ATR} / \mathrm{G}_{2}$ DNA damage checkpoint in our oncogenic response model.

\section{DISCUSSION}

The fact that patients with Fanconi anemia (FA) gene mutations have high predisposition to leukemia and other cancers indicates that FA disease progression involves oncogenic transformation. Little is known about the mechanism by which these mutant cells respond to oncogenic activation. In the present study, we investigated the response of FA HSPCs to oncogene insults and found that the FA pathway plays an important role in response to oncogenic stress. There are several findings that highlight the significance of our study: 1) FA HSPCs displayed an aberrant short-lived response to oncogenic stress induced by activated K-ras or c-Myc; 2) Fanca deficiency compromises K-ras ${ }^{\mathrm{G} 12 \mathrm{D}}$-induced arginine methylation of p53 accompanied by downregulated PRMT5; 3) forced expression of PRMT5 in $\mathrm{Fanca}^{-/}$HSPCs prolonged oncogenic response and delayed leukemia development in irradiated recipient mice. Based on these observations, we propose a model in which the FA proteins in WT cells may play a role in regulating PRMT5-mediated p53 arginine methylation in response to oncogenic stress leading to 
prolonged oncogenic response. On the other hand, the regulatory function of PRMT5 on p53 is diminished in Fanca- or Fancc-deficient cells, which leads to decreased p53 arginine methylation and short-live oncogenic response (Figure 5E).

An important and novel finding of the present study is the short-lived response of FA HSPCs to oncogenic insults. It is known that FA patients have an increased susceptibility to cancer including leukemia $[1-3,8$, $19,20]$. This may be resulted from increased genomic instability, as cells from FA patients are defective in repair of DNA damage induced by certain genotoxic agents $[4,5,8,20]$. Genes encoding proteins with cancerpromoting (oncogenes like K-ras and Myc) or suppressive (tumor suppressors like p53 and ATM) activities in FA cells may be vulnerable to alterations due to a deficit in DNA repair. These alterations may create mutations that activate oncogenes or inactivate tumor suppressors leading to cancer transformation. How FA HSPCs respond to oncogene activation has not been studied. Here we employed two oncogenic systems, the LSL-K-ras ${ }^{\mathrm{G} 12 \mathrm{D}} /$ CreER transgenic mouse model and the inducible Myc ${ }^{\text {ER }}$ model, and observed a unique phenomenon featuring a short-lived response of FA HSPCs to oncogene activation both in vitro and in vivo. Whether this aberrant short-lived response is the consequence of mutations that disrupt oncogenic signaling pathways remains to be investigated.

We have made effort to identify the signaling pathway that is responsible for the observed short-lived oncogenic response in FA HSPCs. Our results implicate a role of the tumor suppressor p53. Several lines of evidence support this notion: first, the kinetics of oncogene-induced expression of $\mathrm{p} 53$ downstream signaling targets $p 19^{\text {Arf }}$ and $p 21^{\text {Cip } 1 / W A F 1}$ displayed the exact pattern of the expression of the Gadd45 $\beta$-luciferase transgene and $p 16^{I N K 4 a}$ in $\mathrm{Fanca}^{-/}$ HSPCs (Figures 2A, 2B, 2C, 2D and Figure 3A). Second, deletion of the Trp53 gene abrogated both the long-lasting and the short-lived oncogenic responses in WT and $\mathrm{Fanca}^{-/-}$LSL-K-ras ${ }^{\mathrm{G} 12 \mathrm{D}} / \mathrm{CreER}$ LSK cells, respectively (Figure 3B, Upper). Third, p53 loss completely abolished p21 $1^{\text {Cip } 1 / W A F 1}$ expression, which is absolutely required for the survival of HSPCs, in response to K-ras activation in both WT and $\mathrm{Fanca}^{-/}$LSL-K-ras ${ }^{\mathrm{G} 12 \mathrm{D} / \mathrm{CreER} \text { LSK cells }}$ (Figure 3B, Lower). Reduced level of p21 may lead to increased apoptosis upon oncogene induction and p53/p21 deficiency could simultaneously cause DNA damage and de-regulate cell cycle leading to mitotic catastrophe. These results thus identify the p53 tumor suppressor pathway that interplays with the FA pathway in oncogenic response. In addition, our finding further corroborates the previous reports that loss of p53 increases cancer development in patients with FA and FA knockout mice [34-36].

Our results also suggest that an alteration of p53 protein level or activity during time window of 4-24 hours following K-ras activation might account for the short-lived oncogenic response in $\mathrm{FanCa}^{-/}$LSL-K-ras ${ }^{\mathrm{G} 12 \mathrm{D} /}$ CreER LSK cells. The observation that there was no difference in p53 protein level between WT and $\mathrm{Fanca}^{-/}$ LSK cells during the 2-24 hours period of K-ras activation (Figure 3C), shifted our attention to an altered p53 activity. In normal cells, cellular stresses including oncogenic activation initiates a signaling network involving
A
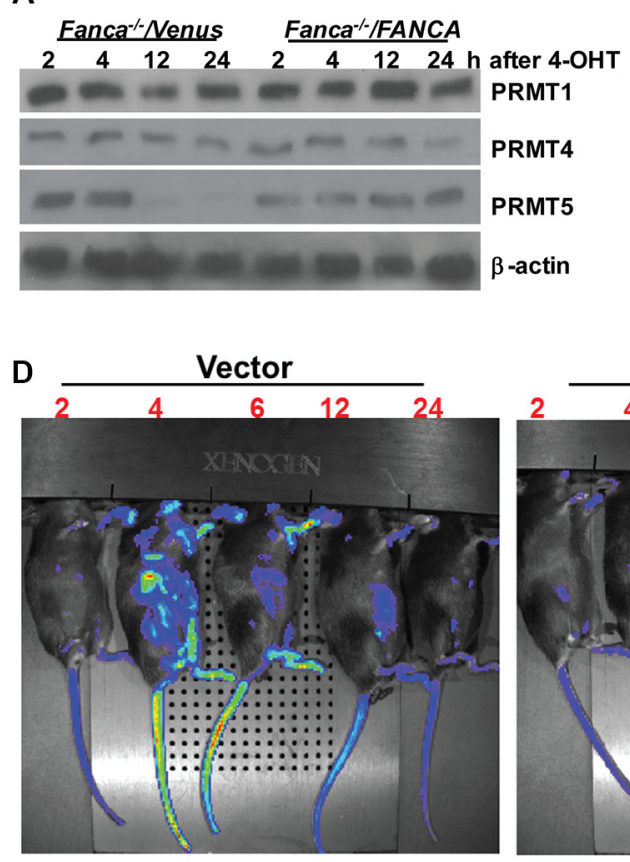

B

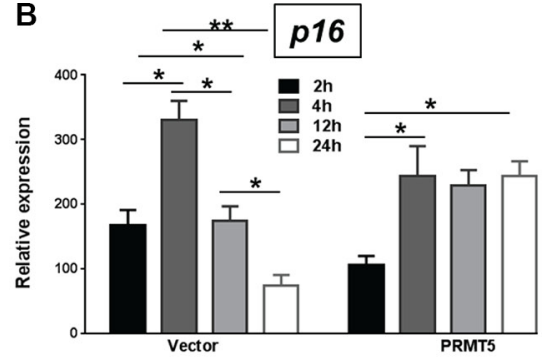

PRMT5

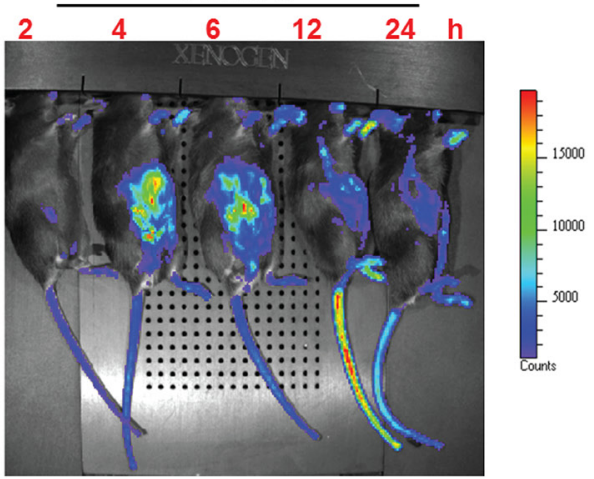

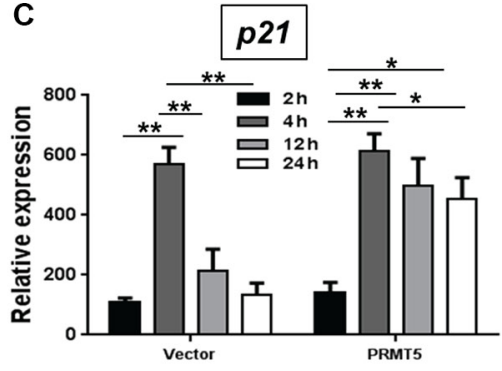
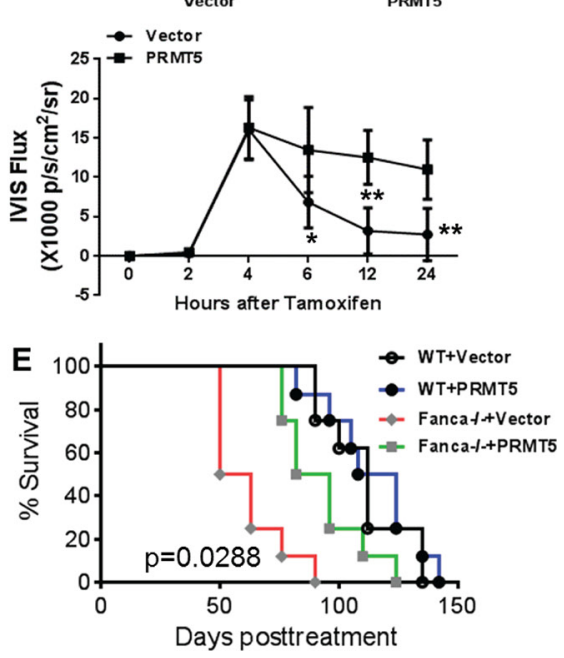


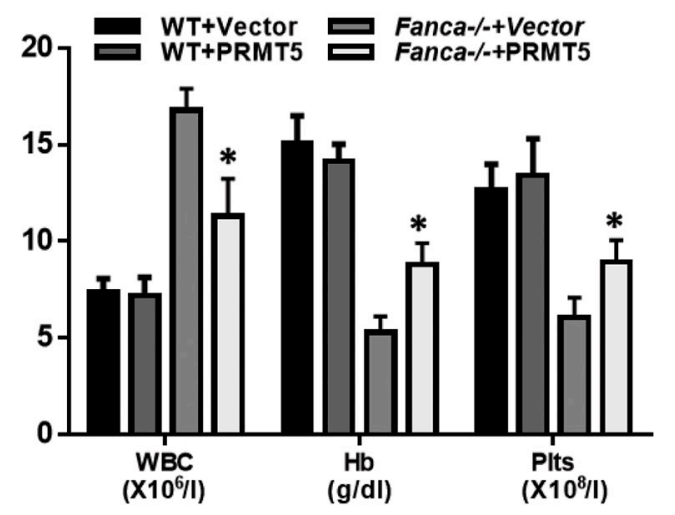

G

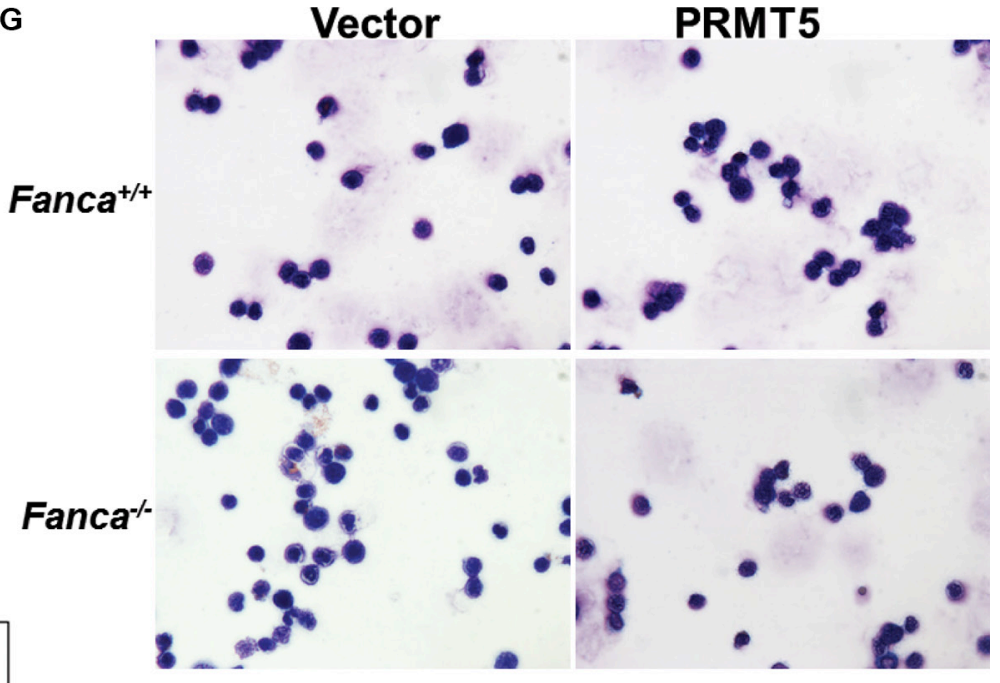

Figure 4: PRMT5-mediated arginine methylation of p53 prevents short-lived oncogenic response. (A) Progressive decline of PRMT5 in FA HSPCs in response to oncogenic stress. Lin cells isolated from Luc-LSL-Fanca///K-ras/CreER or Luc-LSLFanca $^{-/ /} / \mathrm{K}$-ras/CreER mice were transduced with retroviral vector expressing Venus or Venus/FANCA. Sorted Venus ${ }^{+}$cells were then cultured in the presence of 4-OHT for 2 hours then released in fresh medium for the indicated time intervals. Whole cell lysates (WCL) was then extracted from the transduced cells for immunoblotting using antibodies against PRMT1, PRMT4, PRMT5 and $\beta$-actin. (B, C) Overexpression of PRMT5 abrogates the short-lived K-ras-induced $p 16^{I N K t a}$ and $p 21^{\text {CiplWWAFI }}$ expression in FA HSPCs. Lin- cells isolated from Luc-LSL-Fanca ${ }^{-/} / \mathrm{K}$-ras/CreER mice were transduced with lentiviral vector expressing eGFP or eGFP/PRMT5. Sorted eGFP ${ }^{+}$LSK cells were cultured in the presence of 4-OHT for 2 hours then released in fresh medium for the indicated time intervals, followed by RNA extraction and qPCR analysis using primers for $p 16(\mathrm{~B})$ and $p 21^{C \text { ipl IWAFI }}(\mathrm{C})$. Samples were normalized to the level of GAPDH mRNA. (D) Overexpression of PRMT5 lengthens the oncogenic response. Cells described in (B) were transplanted into lethally irradiated BoyJ recipients. 4 months post BMT, single dose of tamoxifen was injected to the recipient animals followed by IVIS imaging at different time points. Luminescence scale is in $\mathrm{p} / \mathrm{s} / \mathrm{cm} 2 / \mathrm{sr}$. The bioluminescent image signals were quantified using LiveImage Pro. 2.0 software. Results are means \pm standard deviation (SD) of 3 independent experiments ( $n=6$ per group). (E) Ectopic PRMT5 expression delays leukemia development. Survival of recipients described in (D) was monitored and plotted by the Kaplan-Meier curve method ( $n=19$ per group). The difference in the recipients transplanted with $\mathrm{Fanca}^{-/}$plus vector versus $\mathrm{Fanca}^{-/-}$plus PRMT5 reaches a $p$ value of 0.0288 (Log-rank test). Controls without tamoxifen (the "0" time-point controls) are depicted in Supplementary Figures. (F) Blood count of the leukemic mice. Peripheral blood from the mice described in (D) was subjected to blood count using HemaVet 950. Quantifications are shown $(n=6$ per group). (G) Wright-Gimesa staining of bone marrow. Bone marrow samples from the recipients described in (D) were subjected to WrightGimesa staining. Representative images are shown. (H) Increased infiltration of myeloid blasts in spleen. Splenocytes from the recipients described in (D) were subjected to Flow cytometry analysis for myeloid blast. Representative flow plots (Left) and quantifications (Right) are shown ( $n=6$ per group).

enzymes that target p53 in the form of post-translational modifications, such as phosphorylation, acetylation and methylation [54]. Protein arginine methylation is mediated by a group of protein arginine methyltransferases (PRMTs) an important process and involved in the regulation of gene expression, RNA metabolism and protein function [55]. Remarkably, we showed that Fanca deficiency compromised K-ras ${ }^{\mathrm{G} 12 \mathrm{D}}$-induced arginine methylation of p53 accompanied by downregulated PRMT5 and that forced expression of PRMT5 in $\mathrm{Fanca}^{-/-}$HSPCs 
prolonged oncogenic response and delayed leukemia development in irradiated recipient mice (Figure 4). Thus, these studies defined a compromised oncogene-induced arginine methylation of p53 by PRMT5 as one mechanism for the short-lived oncogenic stress response in FA HSPCs.

The apparent tumor-suppressor role of PRMT5 identified in this work is in contrast to a recent study of Li et al. who demonstrated that PRMT5 for the inhibition of p53-dependent tumor suppression in response to oncogenic insults [57]. We noted three major differences in the experimental systems between our studies and those of Li et al. Firstly, while the study by Li et al. shows that PRMT5 is required for lymphomagenesis driven by multiple oncogenes including cyclin D1, c-MYC, NOTCH1, and MLL-AF9, the authors employed the Cyclin D1 D1T286A oncogenic model for PRMT5related mechanistic studies. On the other hand, we used the K-ras ${ }^{\text {G12D }}$ model. Secondary, all of the studies by $\mathrm{Li}$ et al. were performed in T-cell lymphoma/Leukemia, which is different from our myeloid leukemia model. Lastly, our mouse model is deficient in the FA DNA repair pathway. In addition to these differences, our results appear to be consistent to a recent report, which shows that over-expression of PRMT5 caused cell cycle arrest while PRMT5 depletion resulted in apoptosis [58]. In this context, our study reveals the multiple facets of PRMT5 response to oncogenic activation. The mechanism by which PRMT5 is deregulated in the FA-deficient cells is not known at the moment. However, our recent proteomic study with a Fancd 2 knock-in mouse model shows that Fancd2 interacts with the murine Prmt5 in vivo (data not shown). We speculate that the FA pathway may play a role in maintaining PRMT5 activity in response to oncogenic stress leading to increased p53 arginine methylation and prolonged oncogenic response.

In conclusion, the present study, using an innovative in vivo model integrating the stress-responsive Gadd $45 \beta$ luciferase transgene and inducible oncogenes (LSL-K-
A

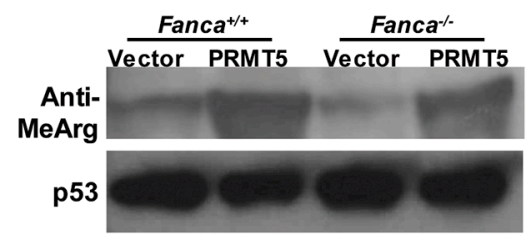

B
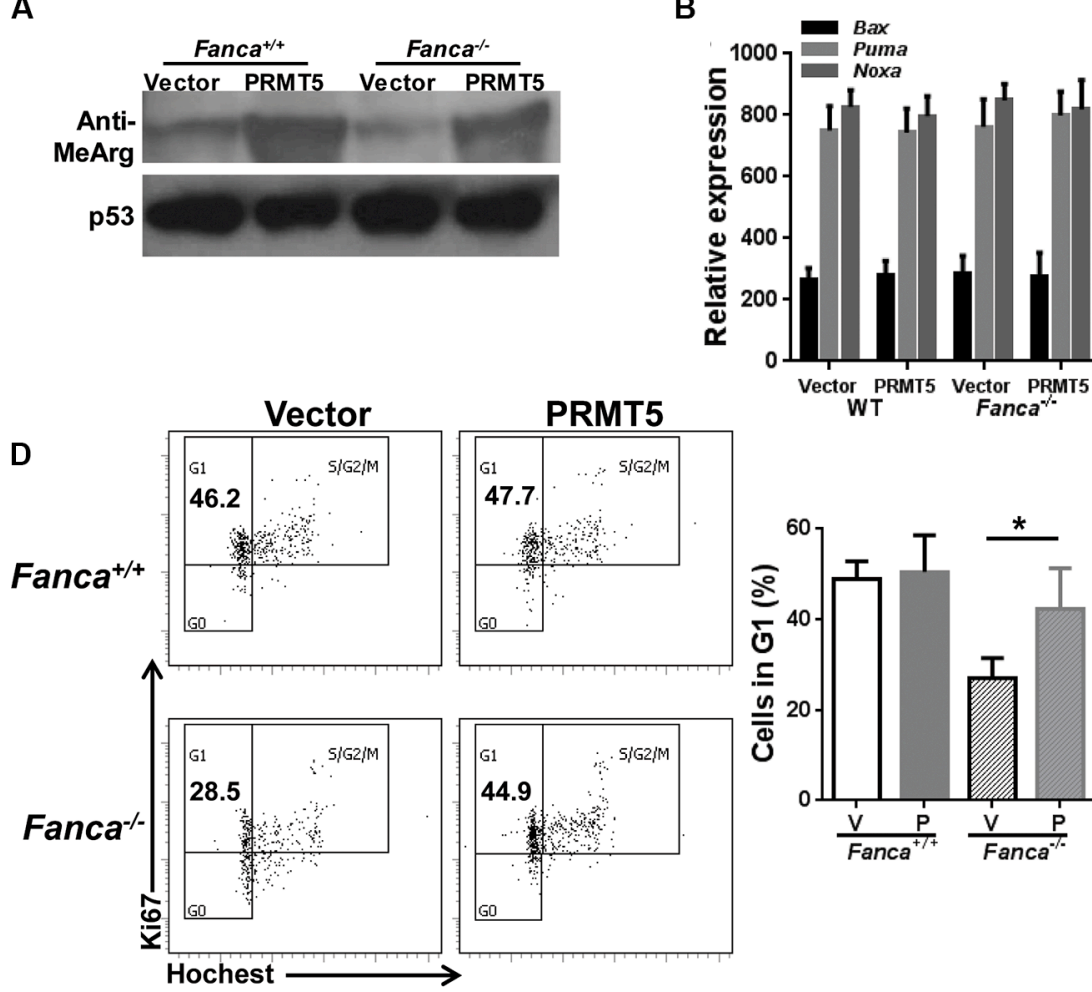

c
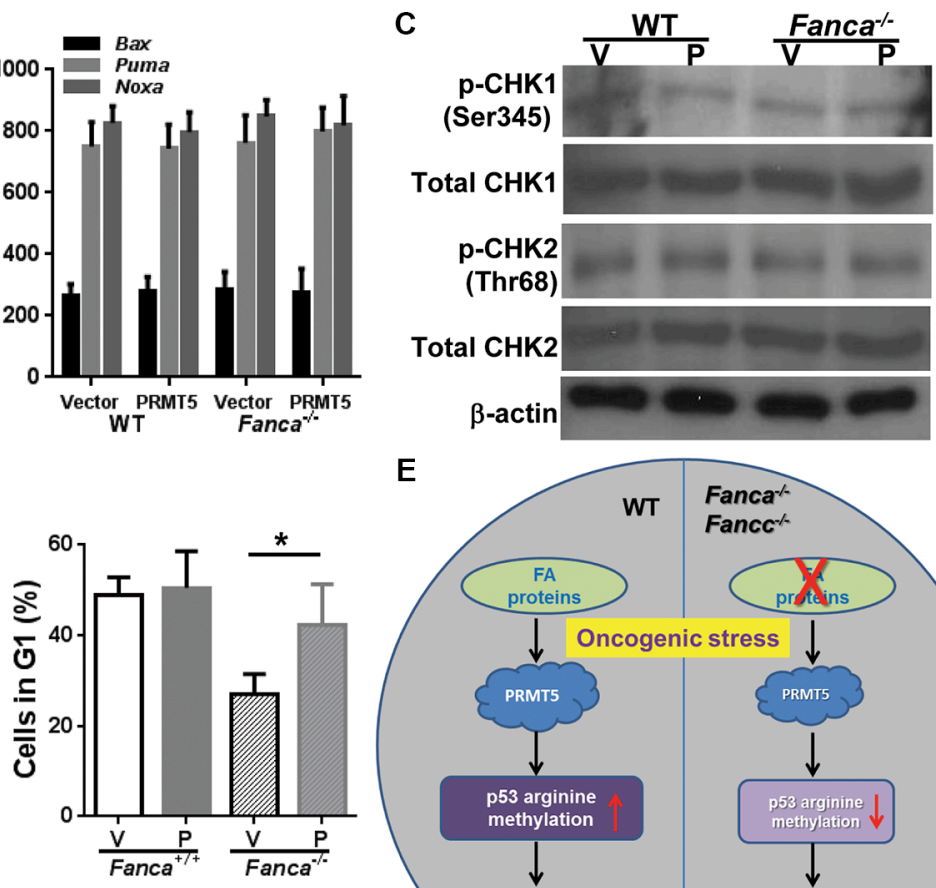

E

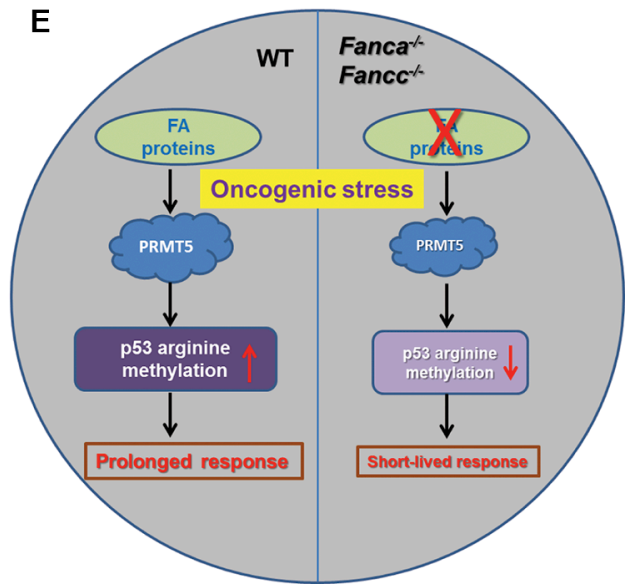

Figure 5: Forced expression of PRMT5 does not affect ATM/ATR pathway. (A) Ectopic PRMT5 expression increased arginine methylation of $\mathrm{p} 53$ in $\mathrm{Kras}^{\mathrm{G} 12 \mathrm{D}}$-expressing WT and $\mathrm{Fanca}^{-/-}$leukemic cells. Lin cells isolated from Luc-LSL-Fanca ${ }^{-/} / \mathrm{K}-\mathrm{ras} / \mathrm{CreER}$ mice were transduced with lentiviral vector expressing eGFP or eGFP/PRMT5. Sorted eGFP ${ }^{+}$LSK cells were transplanted into lethally irradiated BoyJ recipients. 4 months post BMT, single dose of tamoxifen was injected to the recipient animals. Whole cell lysates were extracted from Lin cells isolated from leukemic mice followed by immunoprecipitation using anti-p53 antibody and probed with antibodies against monomethyl arginine or p53, respectively. (B) Ectopic expression of PRMT5 does not affect apoptotic gene expression. RNA was extracted from cells described in (A) followed by qPCR analysis using primers for Bax, Puma or Noxa. (C) Forced expression of PRMT5 does not alter CHK1 or CHK2 phosphorylation. Whole cell lystates extracted from cells described in (B) were subjected to immunoblotting using antibodies against phosphor-CHK1 (Ser245), total CHK1, phosphor-CHK2 (Thr68), total CHK2 or $\beta$-actin. (D) Forced expression of PRMT5 prolonged the short-lived $\mathrm{G}_{1}$ arrest induced by K-ras activation in $\mathrm{Fanca}^{-/-}$leukemic cells. Cells described in (B) were cultured in the presence of 4-OHT for 2 hours then released in fresh medium for 72 hours followed by cell cycle analysis. Representative images and quantification were shown. (E) Model of PRMT5-p53 Arg-methylation in oncogenic response. 
$\operatorname{ras}^{\mathrm{G} 12 \mathrm{D}}$ and $\left.\mathrm{Myc}^{\mathrm{ER}}\right)$, uncovers two novel and significant findings: (i) normal HSPCs utilize arginine methylation of p53 by PRMT5 to orchestrate long-lasting oncogenic response. (ii) FA deficiency leads to a complete reversal of the response pattern characterized by short-lived oncogenic stress response accompanied with aberrant oncogene-induced arginine methylation of p53 resulted from a progressive decline in PRMT5 in FA HSPCs. Our studies indicate that a dysregulated PRMT5 in FA HSPCs plays an important role in suppressing p53-dependent tumor surveillance and suggest that PRMT5 may be a putative therapeutic target in FA tumorigenesis.

\section{MATERIALS AND METHODS}

\section{Mice and treatment}

$\mathrm{FanCa}^{+/+}, \mathrm{FanCa}^{-/-}$and $\mathrm{Fancc}^{+/+}, \mathrm{Fancc}^{-/}$mice were generated by interbreeding the heterozygous $\mathrm{Fanca}^{+/-}$ or $\mathrm{Fancc}^{+/}$mice [59, 60], respectively. Heterozygous $\mathrm{FanCa}^{+/}$or $\mathrm{Fancc}^{+/}$mice were also interbred with the heterozygous Luc-Gadd $45 \beta$ mice [40] to generate Luc$\mathrm{FanCa}^{+/}$and Luc-Fancc ${ }^{+/}$mice. Luc-Fanca ${ }^{+/+}$, Luc$\mathrm{Fanca}^{-/-}$, Luc-Fancc ${ }^{+/+}$, and Luc-Fancc ${ }^{-/-}$mice were generated by interbreeding the heterozygous Luc-Fanca ${ }^{+/}$ or Luc-Fancc ${ }^{+/}$mice. Luc-LSL-K-Ras ${ }^{\mathrm{G} 12 \mathrm{D} / \mathrm{CreER}-}$

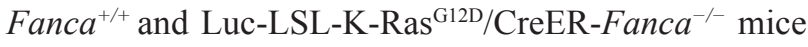
were generated by interbreeding heterozygous LucFanca $^{+/-}$mice with LSL-K-Ras ${ }^{\mathrm{G} 12 \mathrm{D}}$ mice [38] expressing a CreER transgene [61].

For Cre-mediated gene deletion, animals were injected i.p. with $100 \mu \mathrm{l}$ of tamoxifen $(20 \mathrm{mg} / \mathrm{ml}$; SigmaAldrich, St. Louis, MO). Animals were maintained in the animal barrier facility at Cincinnati Children's Hospital Medical Center. All experimental procedures conducted in this study were approved by the Institutional Animal Care and Use Committee of Cincinnati Children's Hospital Medical Center.

\section{Flow cytometry}

The lineage marker (Lin) mixture (BD Biosciences, San Jose, CA) for BM cells from treated or untreated mice included the following biotinylated antibodies: CD3e (145-2C11), CD11b (M1/70), CD45R/B220 (RA3-6B2), mouse erythroid cells Ly-76 (Ter119), Ly6G and Ly-6C (RB6-8C5). Other conjugated antibodies (BD sciences, San Jose, CA) used for surface staining included: CD45.1 (A20), CD45.2 (A104), Sca1 (D7), c-kit (2B8). Biotinylated primary antibodies were detected by incubation of antibody coated cells with streptavidinPerCP or FITC (BD Biosciences, San Jose, CA) in a twostep staining procedure.

For apoptosis staining, LSK cells were cultured in the presence of 4-OHT (125 mM; Sigma-Aldrich, St. Louis, MO) for 24 hours followed by Annexin V and 7AAD staining using BD ApoAlert Annexin V kit
(BD Pharmingen, San Jose, CA) in accordance with the manufacturer's instruction. Apoptosis was analyzed by quantification of Annexin V-positive cell population by flow cytometry.

For cell cycle analysis, LSK cells were cultured in the presence of 4-OHT for 2 hours and released for indicated time intervals followed by staining with propidium iodide (PI) solution containing $1 \mathrm{mg} / \mathrm{mL}$ RNase A. In another set of cell cycle analysis, treated stained cells were fixed and permeabilized with Cytofix/Cytoperm buffer (BD Pharmingen, San Jose, CA) followed by intensive wash using Perm/Wash Buffer (BD Pharmingen, San Jose, CA). Cells were incubated with anti-mouse Ki67 antibody (BD Pharmingen, San Jose, CA) and Hochest 33342 (Sigma-Aldrich, St. Louis, MO) followed by Flow cytometric analysis.

\section{IVIS imaging}

Subjected mice pre-treated with indicated chemicals were injected by an intraperitoneal route with a luciferin solution $(15 \mathrm{mg} / \mathrm{ml}$ in PBS $(150 \mathrm{mg} / \mathrm{kg}))$ that is allowed to distribute in awake animals for about 5-15 minutes. The mice are placed into a clear plexiglass anesthesia box (2.5-3\% isofluorane) that allows unimpeded visual monitoring of animals. After the mice are fully anesthetized, they are transferred from the box to the nose cones attached to the manifold in the imaging chamber. The first image is taken approximately 5 minutes after luciferin injection. Continue to take images at indicated time points after the injection using IVIS series preclinical in vivo Imaging systems (PerkinElmer, Santa Clara, CA). The bioluminescence image signals were quantified by measuring photon flux using LiveImage Pro. 2.0 software (Caliper Life Science, Hopkinton, MA) as previously reported [62]. Briefly, specific areas of the image were analyzed by creating regions of interest (ROI) and measured the average \# of photo/second. After subtracting the signal background of luciferin injected animals at time 0 , the net photon flux $\left(\mathrm{p} / \mathrm{s} / \mathrm{cm}^{2} / \mathrm{sr}\right)$ and the photon flux were normalized to the respective values obtained at different time points after Tamoxifen injection and were plotted versus days after injection. GraphPad Prism was subsequently used to generate graphs for this manuscript.

\section{Isolation of BM lineage-depleted cells}

The femora and tibiae were harvested from the mice immediately after their sacrifice with $\mathrm{CO}_{2}$. Bone marrow (BM) cells were flushed from bones into Iscove's modified Dulbecco's medium (IMDM; Invitrogen, Grand Island, NY) containing 10\% FCS, using a 21-guage needle and syringe. Low-density BM mononuclear cells (LDBMMNCs) were separated by Ficoll Hypaque density gradient (Sigma-Aldrich, St. Louis, MO) and washed with IMDM medium. LDBMMNCs were depleted of 
lineage-committed cells using a lineage cell depletion kit (Miltenyi Biotec, San Diego, CA) in accordance with the manufacturer's instruction.

\section{Colony-forming unit assay}

LSK cells $\left(\mathrm{Lin}^{-S c a} 1^{+} \mathrm{c}-\mathrm{kit}^{+}\right.$cells) were cultured with 4-OHT (125 mM; Sigma-Aldrich, St. Louis, MO) for 48 hours followed by plating in a $35-\mathrm{mm}$ tissue culture dish in $4 \mathrm{~mL}$ of semisolid medium containing $3 \mathrm{~mL}$ of MethoCult M3134 (Stem Cell Technologies, Vancouver, $\mathrm{BC}$, Canada) and the following growth factors: $100 \mathrm{ng} / \mathrm{mL}$ SCF, $10 \mathrm{ng} / \mathrm{mL}$ IL-3, $100 \mathrm{ng} / \mathrm{mL}$ GM-CSF, and 4 units $/ \mathrm{mL}$ erythropoietin (Peprotech, Burlington, NC). On day 7 after plating, erythroid and myeloid colonies were enumerated. Hematopoietic clonal growth results were expressed as means (of triplicate plates) \pm SD of three experiments.

\section{Quantitative PCR analysis}

LSK cells were cultured in the presence of 4-OHT for 2 hours then released in fresh medium for the indicated time intervals. RNA was then extracted for qPCR analysis using primers listed in Table S1. Samples were normalized to the level of GAPDH mRNA.

\section{Viral expression vectors}

The lentiviral vector expressing FLAG-tagged fulllength FANCA was described previously [63]. The Myctagged full-length human PRMT5 cDNA was subcloned into lentiviral vector $\mathrm{pLVX}$-IRES-GFP vector (Clontech, Mountain View, CA), using the gateway system (Life Technologies, Grand Island, NY). The MSCV-IRESGFP-Myc ${ }^{\mathrm{ER}}$ retroviral vector was a gift from Dr. Cleveland JL at St. Jude Children's Research Hospital [39]. The plasmids (10 $\mu \mathrm{g}$ each) were used to produce retroviral supernatant.

\section{Bone marrow transplantation}

BM Lin- cells isolated from either Luc-Fanca ${ }^{+/+}$ or Luc-Fanca ${ }^{-/-}$mice were transduced with retroviral vector MSCV-IRES-eGFP-MycER [39]. 1,500 transduced $\mathrm{Fanca}^{+/+}$LSK cells and 3,000 $\mathrm{Fanca}^{-/}$LSK cells, along with $3 \times 10^{5} \mathrm{BM}$ cells from congenic BoyJ mice, were subjected to bone marrow transplantation (BMT) into lethally irradiated BoyJ recipients. For BMT of Luc-LSLK-Ras ${ }^{\mathrm{G} 12 \mathrm{D}} / \mathrm{CreER}$ cells, 1,000 LSK cells from Luc-LSL-K$\mathrm{Ras}^{\mathrm{G} 12 \mathrm{D}} / \mathrm{CreER}-\mathrm{Fanca}^{+/+}$mice or 2,000 LSK cells from LucLSL-K-Ras ${ }^{\mathrm{G} 12 \mathrm{D}} / \mathrm{CreER}-\mathrm{Fanca}^{-/-}$mice, along with $3 \times 10^{5} \mathrm{BM}$ cells from congenic BoyJ mice, were used. Four months post BMT, donor-derived chimera was determined by Flow Cytometric analysis. The animals were then subjected to the indicated in vivo treatment and IVIS imaging.
Preparation of cell extracts, immunoblotting and immunoprecipitation

To prepare protein lysates, sorted Lin- cells were washed with ice-cold PBS, and resuspended in icecold lysis buffer containing $50 \mathrm{mmol} / \mathrm{L}$ Tris-HCL $(\mathrm{pH}$ 7.4), $0.1 \% \mathrm{NP} 40$, and $1 \mathrm{~mol} / \mathrm{L} \mathrm{NaCl}$ supplemented with protease and phosphatase inhibitors $[10 \mu \mathrm{g} / \mathrm{mL}$ aprotinin, $25 \mu \mathrm{g} / \mathrm{mL}$ leupeptin, $10 \mu \mathrm{g} / \mathrm{mL}$ pepstatin A, $2 \mathrm{mmol} / \mathrm{L}$ phenylmethylsulfonyl fluoride, $0.1 \mathrm{~mol} / \mathrm{L} \quad \mathrm{NaP}_{2} \mathrm{O}_{4}$, $25 \mathrm{mmol} / \mathrm{L} \mathrm{NaF}$, and $2 \mathrm{mmol} / \mathrm{L}$ sodium orthovandate] for $30 \mathrm{~min}$ on ice. Cell debris was removed from the lysates by centrifuging them at $14,000 \mathrm{rpm}$ for $30 \mathrm{~min}$. Protein concentration was quantified by using Bio-Rad reagent and resolved on SDS-PAGE and transferred onto nitrocellulose membranes. Immunoblots were then incubated with primary antibodies specific for $\mathrm{p} 53$ (R\&D, Minneapolis, MN), PRMT1, PRMT4, PRMT5 (Abcam, Cambridge, MA), phospho-CHK1 (Ser345), total CHK1, phosphoCHK2 (Thr68), total CHK2 (all from Cell Signaling Technology, Danvers, MA), or $\beta$-actin (Sigma-Aldrich, St. Louis, MO). Quantitative analysis was performed by utilizing ImageJ software (NIH).

For immunoprecipitation, protein $\mathrm{A} / \mathrm{G}$ agarose beads (Santa Cruz Biotechnologies, Dallas, Texas) precleaned cell lysates were incubated with p53 antibody (R\&D, Minneapolis, MN) by gentle rocking overnight at $4{ }^{\circ} \mathrm{C}$ followed by incubation with protein $\mathrm{A} / \mathrm{G}$ agarose beads for additional 1 hour at $4^{\circ} \mathrm{C}$. Pellets were then washed with $500 \mathrm{ml}$ of lysis buffer and resuspended with $20 \mathrm{ml}$ of $4 \mathrm{X}$ SDS sample buffer. Immunoblots were then incubated with primary antibodies specific for phosphor-serine (Millipore, Billerica, MA), acetylated lysine (Abcam, Cambridge, MA), methylated lysine (Abcam, Cambridge, MA), or mono-methyl arginine (Cell Signaling, Danvers, MA) antibodies for 12 to $16 \mathrm{~h}$ at 4 degree. Signals were revealed after incubation with anti-mouse or anti-rabbit secondary antibodies.

\section{Statistics}

Data were analyzed statistically using a Student's $t$ test. The level of the statistical significance stated in the text was based on the $P$ values. $P<0.05$ was considered statistically significant.

\section{ACKNOWLEDGMENTS}

We thank Dr. Cleveland JL at St. Jude Children's Research Hospital for the MSCV-IRES-GFP-Myc ${ }^{\text {ER }}$ retroviral vector. There is no conflict of interest to disclose on the part of any author.

\section{CONFLICTS OF INTEREST}

The authors declare no competing financial interests. 


\section{Authors' contributions}

W.D. designed research, performed research, analyzed data, and wrote the paper; S.A., O.E., A.W. performed research and Q.P. designed research and wrote the paper.

\section{GRANT SUPPORT}

This work was supported by National Institutes of Health (Heart, Lung and Blood Institute) grant R01 HL076712 and (National Cancer Institute) grant R01 CA157537. Q.P. is supported by a Leukemia and Lymphoma Scholar award. W.D. is supported by a National Institutes of Health, Institutional Research Training T32 grant and National Natural Science Foundation of China (NNSFC) 81470288.

\section{REFERENCES}

1. Bagby GC Jr. Genetic basis of Fanconi anemia. Curr Opin Hematol. 2003; 10:68-76.

2. Tischkowitz MD, Hodgson SV. Fanconi anaemia. J Med Genet. 2003; 40:1-10.

3. Kennedy RD, D'Andrea AD. The Fanconi Anemia/BRCA pathway: new faces in the crowd. Genes Dev. 2005; 19:2925-2940.

4. Meyer S, Neitzel H, T"onnies H. Chromosomal aberrations associated with clonal evolution and leukemic transformation in Fanconi anemia: clinical and biological implications. Anemia. 2012; 2012:349837.

5. Deans AJ, West SC. DNA interstrand crosslink repair and cancer. Nat Rev Cancer. 2011; 11:467-480.

6. Sawyer SL, Tian L, Kähkönen M, Schwartzentruber J, Kircher M, University of Washington Centre for Mendelian Genomics FORGE Canada Consortium, Majewski J, Dyment DA, Innes AM, Boycott KM, Moreau LA, Moilanen JS, Greenberg RA. Biallelic Mutations in BRCA1 Cause a New Fanconi Anemia Subtype. Cancer Discov. 2015; 5:135-142.

7. Dong H, Nebert DW, Bruford EA, Thompson DC, Joenje H, Vasiliou V. Update of the human and mouse Fanconi anemia genes. Hum Genomics. 2015; 9:32.

8. Du W, Erden O, Pang Q. TNF- $\alpha$ signaling in Fanconi anemia. Blood Cells Mol Dis. 2013; 52:2-11.

9. Niedernhofer LJ, Lalai AS, Hoeijmakers JH. Fanconi anemia (cross) linked to DNA repair. Cell. 2005; 123:1191-1198.

10. Patel KJ, Joenje H. Fanconi anemia and DNA replication repair. DNA Repair (Amst). 2007; 6:885-890.

11. Pace P, Mosedale G, Hodskinson MR, Rosado IV, Sivasubramaniam M, Patel KJ. Ku70 corrupts DNA repair in the absence of the Fanconi anemia pathway. Science 2010; 329:219-223.

12. Wilson JB, Yamamoto K, Marriott AS, Hussain S, Sung P, Hoatlin ME Mathew CG, Takata M, Thompson LH,
Kupfer GM, Jones NJ. FANCG promotes formation of a newly identified protein complex containing BRCA2, FANCD2 and XRCC3. Oncogene. 2008; 27:3641-3652.

13. Elson A, Deng C, Campos-Torres J, Donehower LA, Leder P. The MMTV/c-myc transgene and p53 null alleles collaborate to induce T-cell lymphomas, but not mammary carcinomas in transgenic mice. Oncogene. 1995; 11:181-190.

14. Halazonetis TD, Gorgoulis VG, Bartek J. An oncogeneinduced DNA damage model for cancer development. Science. 2008; 319:1352-1355.

15. Strasser A, Harris AW, Bath ML, Cory S. Novel primitive lymphoid tumours induced in transgenic mice by cooperation between myc and bcl-2. Nature. 1990; 348:331-333.

16. Blasco RB, Francoz S, Santamaría D, Cañamero $M$, Dubus P, Charron J Baccarini M, Barbacid M. c-Raf, but not B-Raf, is essential for development of K-Ras oncogenedriven non-small cell lung carcinoma. Cancer Cell. 2011; 19:652-663.

17. Braig M, Pällmann N, Preukschas M, Steinemann D, Hofmann W, Gompf Streichert T, Braunschweig T, Copland M, Rudolph KL, Bokemeyer C, Koschmieder S, Schuppert A, et al. A 'telomere-associated secretory phenotype' cooperates with BCR-ABL to drive malignant proliferation of leukemic cells. Leukemia. 2014; 28:2028-2039.

18. Valsesia-Wittmann S, Magdeleine $M$, Dupasquier S, Garin E, Jallas AC, Combaret V Krause A, Leissner P, Puisieux A.. Oncogenic cooperation between H-Twist and $\mathrm{N}-\mathrm{Myc}$ overrides failsafe programs in cancer cells. Cancer Cell. 2004; 6:625-630.

19. Buchwald M, Moustacchi E. Is Fanconi anemia caused by a defect in the processing of DNA damage? Mutat Res1998; 408:75-90.

20. Nalepa G, Enzor R, Sun Z, Marchal C, Park SJ, Yang Y Tedeschi L, Kelich S, Hanenberg H, Clapp DW. Fanconi anemia signaling network regulates the spindle assembly checkpoint. J Clin Invest. 2013; 123:3839-3847.

21. Giaccia AJ, Kastan MB. The complexity of p53 modulation: emerging patterns from divergent signals. Genes Dev. 1998; $12: 2973-2983$

22. Lohrum MA, Vousden KH. Regulation and activation of p53 and its family members. Cell Death/Differ. 1999; 6:1162-1168.

23. Jin S, Levine AJ. The p53 functional circuit. J Cell Sci. 2001; 114:4139-4140.

24. Levine AJ, Oren M. The first 30 years of $\mathrm{p} 53$ : growing ever more complex. Nat Rev Cancer. 2009; 9:749-758.

25. Rani R, Li J, Pang Q. Differential p53 engagement in response to oxidative and oncogenic stresses in Fanconi anemia mice. Cancer Res. 2008; 68:9693-9702.

26. Milyavsky M, Gan OI, Trottier M, Komosa M, Tabach O, Notta F, Lechman E, Hermans KG, Eppert K, Konovalova Z, Ornatsky O, Domany E, et al. A distinctive 
DNA damage response in human hematopoietic stem cells reveals an apoptosis-independent role for p53 in selfrenewal. Cell Stem Cell. 2010; 7:186-197.

27. Chen J, Ellison FM, Keyvanfar K, Omokaro SO, Desierto MJ, Eckhaus MA, Young NS. Enrichment of hematopoietic stem cells with SLAM, LSK markers for the detection of hematopoietic stem cell function in normal and Trp53 null mice. Exp Hematol. 2008; 36:1236-1243.

28. Liu Y, Elf SE, Miyata Y, Sashida G, Liu Y, Huang G, Di Giandomenico S, Lee JM, Deblasio A, Menendez S, Antipin J, Reva B, Koff A, et al. p53 regulates hematopoietic stem cell quiescence. Cell Stem Cell. 2009; 4:37-48.

29. TeKippe M, Harrison DE, Chen J. Expansion of hematopoietic stem cell phenotype and activity in Trp53null mice. Exp Hematol. 2003; 31:521-527.

30. Meng A, Wang Y, Van Zant G, Zhou D. Ionizing radiation and busulfan induce premature senescence in murine bone marrow hematopoietic cells. Cancer Res. 2003; 63:5414-5419.

31. Wang Y, Schulte BA, Zhou D. Hematopoietic stem cell senescence and long-term bone marrow injury. Cell Cycle. 2006; 5:35-38.

32. Wang YV, Leblanc M, Fox N, Mao JH, Tinkum KL, Krummel K, Engle D, Piwnica-Worms D, Piwnica-Worms H, Balmain A, Kaushansky K, Wahl GM. Fine-tuning p53 activity through C-terminal modification significantly contributes to HSC homeostasis and mouse radiosensitivity. Genes Dev. 2011; 25:1426-1438.

33. Ceccaldi R, Briot D, Larghero J, Vasquez N, Dubois d'Enghien C, Chamousset D Noguera ME, Waisfisz Q, Hermine O, Pondarre C, Leblanc T, Gluckman E, Joenje $H$, et al. Spontaneous abrogation of the $G_{2}$ DNA damage checkpoint has clinical benefits but promotes leukemogenesis in Fanconi anemia patients. J Clin Invest. 2011; 121:184-194.

34. Houghtaling S, Granville L, Akkari Y, Torimaru Y, Olson S, Finegold M, Grompe M.Heterozygosity for p53 (Trp53+/-) accelerates epithelial tumor formation in fanconi anemia complementation group D2 (Fancd2) knockout mice. Cancer Res. 2005; 65:85-91.

35. Freie BW, Ciccone SL, Li X, Plett PA, Orschell CM, Srour EF, Hanenberg H, Schindler D, Lee SH, Clapp DW. A role for the Fanconi anemia $\mathrm{C}$ protein in maintaining the DNA damage-induced G2 checkpoint. J Biol Chem. 2004; 279:50986-50993.

36. Liu TX, Howlett NG, Deng M, Langenau DM, Hsu K, Rhodes J, Kanki JP, D'Andrea AD, Look AT. Knockdown of zebrafish Fancd2 causes developmental abnormalities via p53-dependent apoptosis. Dev Cell. 2003; 5:903-914.

37. Ceccaldi R, Parmar K, Mouly E, Delord M, Kim JM, Regairaz M, Pla M, Vasquez N, Zhang QS, Pondarre C, Peffault de Latour R, Gluckman E, Cavazzana-Calvo M, et al. Bone marrow failure in Fanconi anemia is triggered by an exacerbated p53/p21 DNA damage response that impairs hematopoietic stem and progenitor cells. Cell Stem Cell. 2012; 11:36-49.

38. Johnson L, Mercer K, Greenbaum D, Bronsont RT, Crowley D, Tuveson DA, Jacks T. Somatic activation of the K-ras oncogene causes early onset lung cancer in mice. Nature. 2001; 410:1111-1116.

39. Drissi R, Zindy F, Roussel MF, Cleveland JL. c-Mycmediated regulation of telomerase activity is disabled in immortalized cells. J Biol Chem. 2001; 276:29994-30001.

40. McLean GW, Komiyama NH, Serrels B, Asano H, Reynolds L, Conti F, Hodivala-Dilke K, Metzger D, Chambon P, Grant SG, Frame MC. Specific deletion of focal adhesion kinase suppresses tumor formation and blocks malignant progression. Genes Dev. 2004;18:2998-3003.

41. Harajly M, Zalzali H, Nawaz Z, Ghayad SE, Ghamloush F, Basma H, Zainedin S, Rabeh W, Jabbour M, Tawil A, Badro DA, Evan GI et al. p53 Restoration in Induction and Maintenance of Senescence:Differential Effects in Premalignant andMalignant Tumor Cells. Mol Cell Biol. 2015;36:438-451.

42. Sato M, Vaughan MB, Girard L, Peyton M, Lee W, Shames DS Ramirez RD, Sunaga N, Gazdar AF, Shay JW, Minna JD. Multiple oncogenic changes (K-RAS(V12), p53 knockdown, mutant EGFRs, p16 bypass, telomerase) are not sufficient to confer a full malignant phenotype on human bronchial epithelial cells. Cancer Res. 2006; 66:2116-2128.

43. Shen L, Nishioka T, Guo J, Chen C. Geminin functions downstream of p53 in K-ras-induced gene amplification of dihydrofolate reductase. Cancer Res. 2012; 72:6153-6162.

44. Zhang N, Ahsan MH, Zhu L, Sambucetti LC, Purchio AF, West DB. NF-kappaB and not the MAPK signaling pathway regulates GADD45beta expression during acute inflammation. Biol Chem. 2005; 280:21400-21408.

45. Salvador JM, Brown-Clay JD, Fornace AJ Jr. Gadd45 in stress signaling, cell cycle control, and apoptosis. Adv Exp Med Biol. 2013; 793:1-19

46. Liebermann DA, Tront JS, Sha X, Mukherjee K, MohamedHadley A, Hoffman B. Gadd45 stress sensors in malignancy and leukemia._Crit Rev Oncog. 2011; 16:129-140.

47. Biroccio A, Amodei S, Antonelli A, Benassi B, Zupi G. Inhibition of c-Myc oncoprotein limits the growth of human melanoma cells by inducing cellular crisis. J Biol Chem. 2003; 278:35693-35701.

48. Catalano A, Rodilossi S, Caprari P, Coppola V, Procopio A. 5-Lipoxygenase regulates senescence-like growth arrest by promoting ROS-dependent p53 activation. EMBO J. 2005; 24:170-179.

49. Cam H, Dynlacht BD. Emerging roles for E2F: beyond the G1/S transition and DNA replication. Cancer Cell. 2003; 3:311-316.

50. Kim SJ, Letterio J. Transforming growth factor-beta signaling in normal and malignant hematopoiesis. Leukemia. 2003; 17:1731-1737. 
51. Gritsman K, Yuzugullu H, Von T, Yan H, Clayton L, Fritsch C, Maira SM, Hollingworth G, Choi C, Khandan T, Paktinat M, Okabe RO, Roberts TM, et al. Hematopoiesis and RAS-driven myeloid leukemia differentially require PI3K isoform p110 $\alpha$. J Clin Invest. 2014; 124:1794-1809.

52. Lowe SW. Activation of p53 by oncogenes. Endocr Relat Cancer. 1999; 6:45-48.

53. Scaglioni PP, Rabellino A, Yung TM, Bernardi R, Choi S, Konstantinidou G, Nardella C, Cheng K, Pandolfi PP. Translation-dependent mechanisms lead to PML upregulation and mediate oncogenic K-RAS-induced cellular senescence. EMBO Mol Med. 2012; 4:594-602.

54. Bode AM, Dong Z. Post-translational modification of p53 in tumorigenesis. Nature Reviews. 2004; 4:793-805.

55. Bedford MT, Richard S. Arginine methylation an emerging regulator of protein function. Molecular Cell. 2005; 18:263-272.

56. Durant ST, Cho EC, La Thangue NB. p53 methylation--the Arg-ument is clear. Cell Cycle. 2009; 8:801-802.

57. Li Y, Chitnis N, Nakagawa H, Kita Y, Natsugoe S, Yang Y, Li Z, Wasik M, Klein-Szanto AJ, Rustgi AK, Diehl JA. PRMT5 is required for lymphomagenesis triggered by multiple oncogenic drivers. Cancer Discov. 2015; 5:288-303.

58. Jansson M, Durant ST, Cho EC, Sheahan S, Edelmann M, Kessler B, La Thangue NB. Arginine methylation regulates the p53 response. Nature Cell Biology. 2008; 10:1431-1439.
59. Wong JC, Alon N, Mckerlie C, Huang JR, Meyn MS, Buchwald M. Targeted disruption of exons 1 to 6 of the Fanconi Anemia group A gene leads to growth retardation, strain-specific microphthalmia, meiotic defects and primordial germ cell hypoplasia. Hum Mol Genet. 2003;12:2063-2076.

60. Chen M, Tomkins DJ, Auerbach W, McKerlie C, Youssoufian H, Liu L, Gan O, Carreau M, Auerbach A, Groves T, Guidos CJ, Freedman MH, Cross J, et al. Inactivation of $\mathrm{Fac}$ in mice produces inducible chromosomal instability and reduced fertility reminiscent of Fanconi anaemia. See comment in PubMed Commons belowNat Genet. 1996; 12:448-451.

61. Ventura A, Kirsch DG, McLaughlin ME, Tuveson DA, Grimm J, Lintault L, Newman J, Reczek EE, Weissleder R, Jacks T. Restoration of p53 function leads to tumour regression in vivo. Nature. 2007; 445:661-665.

62. Gill S, Tasian SK, Ruella M, Shestova O, Li Y, Porter DL, Carroll M, Danet-Desnoyers G, Scholler J, Grupp SA, June CH, Kalos M. Preclinical targeting of human acute myeloid leukemia and myeloablation using chimeric antigen receptor-modified T cells. Blood. 2014; $123: 2343-2354$

63. Li X, Erden O, Li L, Ye Q, Wilson A, Du W. Binding to WGR domain by salidroside activates PARP1 and protects hematopoietic stem cells from oxidative stress. Antioxid Redox Signal. 2014; 20:1853-1865. 